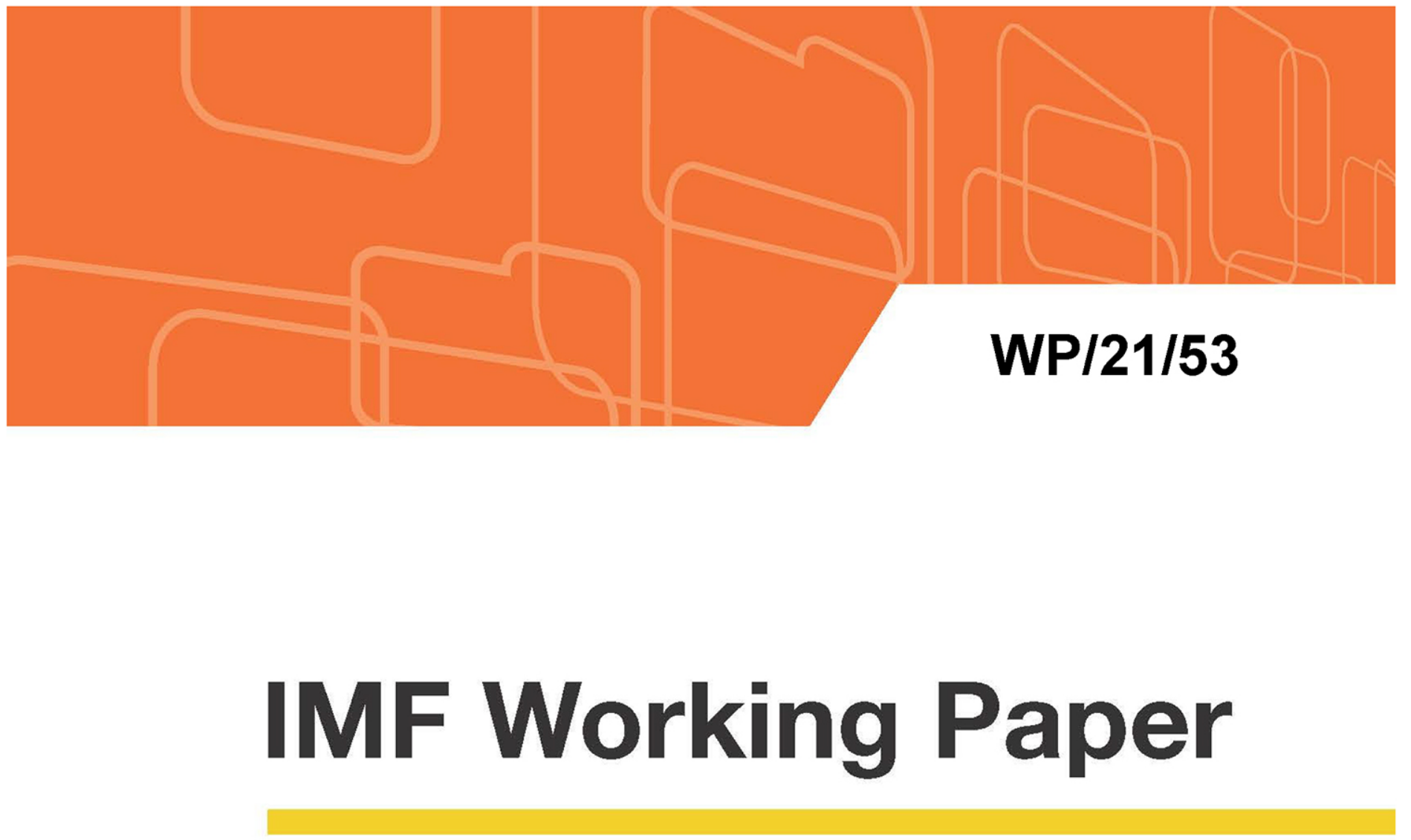

\title{
Pandemics and Inequality: Perceptions and Preferences for Redistribution
}

by Vybhavi Balasundharam and Era Dabla-Norris

IMF Working Papers describe research in progress by the author(s) and are published to elicit comments and to encourage debate. The views expressed in IMF Working Papers are those of the author(s) and do not necessarily represent the views of the IMF, its Executive Board, or IMF management.

$$
\text { I N T E R N A T I O N A L M O N E T A R Y F U N D }
$$




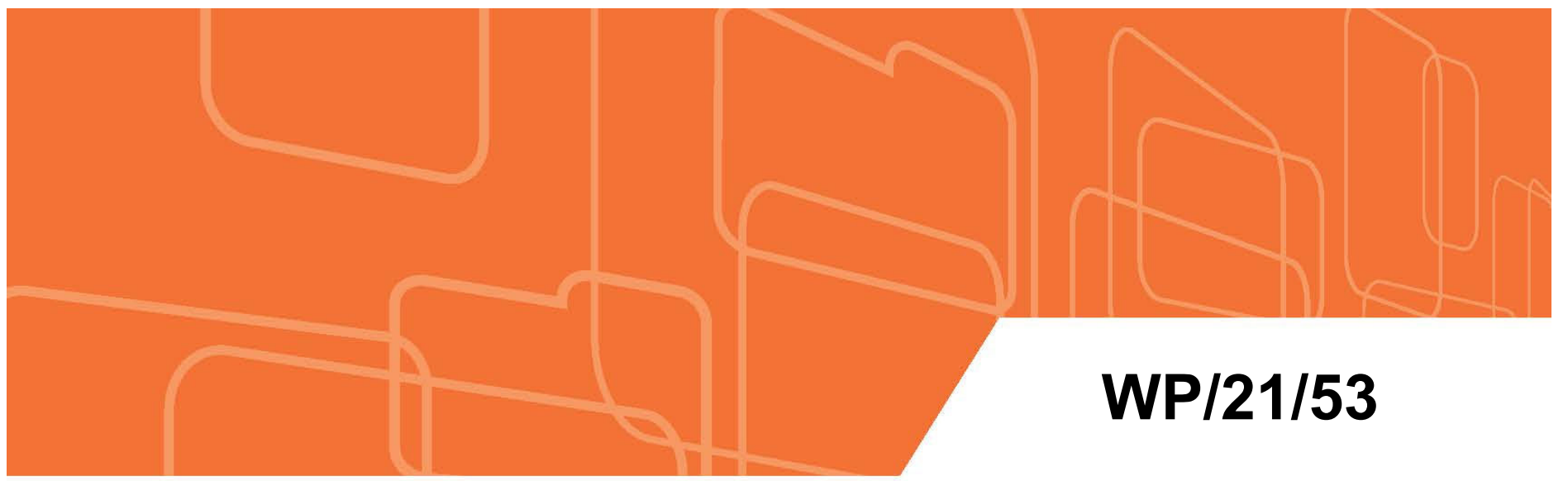

\section{IMF Working Paper}

\section{Pandemics and Inequality: Perceptions and Preferences for Redistribution}

by Vybhavi Balasundharam and Era Dabla-Norris

IMF Working Papers describe research in progress by the author(s) and are published to elicit comments and to encourage debate. The views expressed in IMF Working Papers are those of the author(s) and do not necessarily represent the views of the IMF, its Executive Board, or IMF management.

$$
\text { I N T E R N A T I O N A L M O N E T A R Y F U N D }
$$




\title{
IMF Working Paper
}

Asia and Pacific Department

\section{Pandemics and Inequality: Perceptions and Preferences for Redistribution Prepared by Vybhavi Balasundharam and Era Dabla-Norris*}

Authorized for distribution by Era Dabla-Norris

Febraury 2021

\begin{abstract}
IMF Working Papers describe research in progress by the author(s) and are published to elicit comments and to encourage debate. The views expressed in IMF Working Papers are those of the author(s) and do not necessarily represent the views of the IMF, its Executive Board, or IMF management.
\end{abstract}

\begin{abstract}
This paper uses an individual-level survey conducted by the Edelman Trust Barometer in mid-April for 11 advanced and emerging market economies to examine perceptions of government performance in managing the health and economic crisis, beliefs about the future, and attitudes about redistribution. We find that women, non-college educated, the unemployed, and those in non-teleworkable jobs systematically have less favorable perceptions of government responses. Personally experiencing illness or job loss caused by the pandemic can shape people's beliefs about the future, heightening uncertainties about prolonged job losses, and the imminent threat from automation. Economic anxieties are amplified in countries that experienced an early surge in infections followed by successful containment, suggesting that negative beliefs can persist. Support for pro-equality redistributive policies varies, depending on personal experiences and views about the poor. However, we find strong willingness to provide social safety nets for vulnerable individuals and firms by those who have a more favorable perception of government responses, suggesting that effective government actions can promote support for redistributive policies.
\end{abstract}

JEL Classification Numbers: D63, D79, D84, I38

Keywords: COVID-19, inequality, perceptions, government, political economy

Author’s E-Mail Address: vbalasundharam@imf.org; edablanorris@imf.org

\footnotetext{
${ }^{*}$ We would like to like to thank the Edelman Trust Barometer for sharing the data and participants in the IMF seminar series for their helpful comments.
} 
Table of Contents

I. Introduction

II. Data and Methodology

III. Empirical Approach 11

IV. Results $\underline{12}$

V. Conclusion $\underline{19}$

\section{FIGURES}

1. Individual Characteristics and Overall Government Performance____

2. Individual Characteristics and Socio-Economic Concerns___

3. Individual Characteristics and Role of Government ___

4. Coefficients of Individual Characteristics on Government Responses

5. Coefficients of Individual Characteristics of Socio-Economic Concerns _ _

6. Impact of Region and Age on Preferences for Redistribution (marginal effects) _ _

7. Marginal Effect of Income and Age on Policy Preferences in Advanced Economies_ 18

References 


\section{Introduction}

The disproportionate health and economic effects of COVID-19 on certain demographic groups has elevated concerns that the crisis will exacerbate income inequality. This runs the risk of undermining social cohesion and deepening political polarization in societies. ${ }^{1}$ Has the heterogenous crisis impact influenced perceptions of government responses to mitigate the fallout from the pandemic? How has the crisis impacted beliefs about the future, particularly for those who are personally affected? How has the pandemic shaped preferences for redistributive policies and support for government intervention? Do these attitudes and preferences depend on the level of economic development and country-specific COVID dynamics? Answers to these questions can inform the design of government policy interventions that would garner broad public support.

This paper uses an individual-level, cross-country survey conducted by the Edelman Trust Barometer in mid-April 2020 to examine perceptions of government performance in managing the health and economic crisis, beliefs about the future, and attitudes about redistribution. The survey was conducted for 11 advanced and emerging market economies when most countries in the sample (excluding China and Korea) were facing their first surge in infections and designing and implementing response efforts. This allows us to examine how attitudes and preferences for redistribution were being shaped early on in the pandemic. Our focus lies in understanding the role socio-demographic and occupational characteristics play and examining cross-country drivers.

First, we document systematic differences across gender, employment status, flexibility of work (i.e., whether jobs are tele-workable), region, and income in perceptions of how well governments are handling the economic and health fallout. Women are more likely to have an unfavorable view of government responses compared to men on both the health and economic fronts. This is in line with the evidence that the COVID-19 crisis has had a disproportionate impact on women (Alon et al., 2020). Similarly, non-college educated, the unemployed, and those in jobs that cannot be done from home, who were hit hardest by lockdowns and social distancing measures, perceive the government's performance as less favorable. Compared to their counterparts, urban individuals and those employed in larger firms have a more favorable perception of government responses in handling the health crisis.

While age is generally not a significant determinant of how government responses are perceived, the young have a less favorable perception of the government's health response in emerging market economies. We also find that richer individuals have a more favorable perception of government responses in advanced economies, and in countries where less stringent containment measures were adopted. However, the rich are less supportive of government responses in countries with higher initial levels of inequality.

\footnotetext{
1 See IMF (2020), Adams-Prassl et al. (2020), Brussevich, Dabla-Norris, and Khalid (2020).
} 
Second, we find that compared to their counterparts, older individuals, the economically vulnerable, and those living in urban areas are more worried about the health and economic well-being of vulnerable groups. Individual outlooks on the future are bleak, with heightened anxieties related to prolonged job losses, fears of automation, and harms of capitalism even early-on in the crisis. Decomposing the responses by demographic and occupational characteristics, we find that individuals personally affected by the crisis, either through job loss or those who have had contact with sick people or are personally experiencing symptoms of the disease, hold particularly pessimistic beliefs about the future.

We also find that women are more pessimistic about prolonged job losses in countries where more stringent containment measures were put in place. Concerns about the future are stronger overall for individuals in emerging market economies, despite the lower incidence of COVID-19 cases at the time the survey was conducted. Economic anxieties are also amplified for lesseducated and unemployed respondents in countries which saw an initial surge followed by a downward trend in COVID-19 cases at the time of the survey, suggesting that negative beliefs can persist. Overall, these results suggest that policies should take into account the unequal labor market and health impacts of the pandemic to quell economic anxieties and social discontent. $^{2}$

Finally, we shed light into how the crisis has shaped policy preferences for redistribution. Roughly two-thirds of respondents across countries believe that that the poor have been unfairly burdened with both illness and economic sacrifice, and that redistribution is necessary as a response. We find that people who believe that the poor are unfortunate are more likely to support pro-equality redistributive policies. In particular, we find systematic support for financial assistance to vulnerable businesses and households among the old, college-educated, and individuals in tele-workable jobs, even controlling for income.

Interestingly, we find less willingness to support redistributive policies by those who suffered an adverse health impact on account of the pandemic. This could be interpreted as the crisis making them more risk-averse and less optimistic about the role of government. Despite expressing strong concerns for the economically vulnerable, individuals in urban areas are also less supportive of government interventions. This is in line with Sands (2017) who finds that exposure to socioeconomic inequality in an everyday setting could negatively impact willingness to publicly support redistributive economic policies. However, we find a strong willingness to provide social safety nets for individuals and firms hit hardest by the crisis by those who have a more favorable assessment of government responses to contain the health and economic crisis. This suggests that appropriate and effective government actions can, in turn, promote support for redistributive policies.

\footnotetext{
${ }^{2}$ Liquidity support for the economically vulnerable has been shown to reduce psychological distress and anxieties (Haushofer and Shapiro, 2016; Christian et al., 2019).
} 
Our paper contributes to several strands of the literature. First, this paper contributes to a growing literature that uses cross-country survey data to study trust and perceptions about the government. Both individual and social characteristics such as age, gender, marital status, household size, income, and level of education, employment status are likely to influence trust in the government (Algan et al., 2017; Christensen and Laegreid, 2005; Foster and Frieden, 2017). Using the Worldwide COVID-19 Attitudes and Beliefs dataset, Gozgor (2020) finds that older and healthier individuals tend to trust their governments more, while education is negatively related to trust in governments. Brück et al. (2020) show that those who have had contact with sick people and are unemployed exhibit lower trust in institutions in general. Evidence also suggest that a recent history of misfortune may make people less optimistic about their future and also less likely to trust others (Alesina and Ferrara, 2002; Giuliano and Spilimbergo, 2014). The rapid and widespread impact of COVID-19 crisis compared to more conventional economic downturns can affect support for institutions and belief formation differently. We expand on this literature by documenting individuals' satisfaction with the government's performance during the COVID19 crisis along both the health and economic dimensions.

Second, we contribute specifically to the literature studying economic anxieties in response to the COVID-19 crisis (Bartik et al., 2020; Binder, 2020; Coibion et al., 2020; Daniele et al. 2020; Fetzer et al., 2020; Hanspal et al., 2020). This has largely focused on advanced economies, particularly the US and on the macroeconomic environment, such as unemployment and inflation expectations. In contrast, we study a wider range of countries and concerns about inequality, capitalism and automation, and explore the role of individual characteristics in shaping these concerns. ${ }^{3}$ By understanding the drivers of heterogenous expectations across individuals and countries, the analysis can also shed light on the appropriate design of public policy responses.

Finally, our paper is related to studies that use surveys to elicit policy preferences and beliefs about government effectiveness. Examples include redistribution (Alesina and Giuliano, 2011; Alesina et al. 2018; Kuziemko et al. 2015), austerity (Talving 2017); and welfare spending (Margalit 2013, Algan et al. 2015). There is also a burgeoning literature focusing on trust and compliance with public health measures during COVID-19 (Brodeur et al., 2020; Dabla-Norris, Lima and Khan, forthcoming). Two closely related studies are by Daniele et al. (2020) who study policy preferences regarding taxation for welfare spending in Italy, Germany, Spain and the Netherlands during COVID-19, and Klemm and Mauro (forthcoming) who look at preferences for progress taxation in the US. This paper focuses on preferences for enhancing social safety nets for the vulnerable, in addition to managing the health crisis for a wider set of countries.

This paper is structured as follows. Section II presents the data and methodology, highlighting broad patterns in the data. Section III presents the main findings, and Section IV concludes.

\footnotetext{
${ }^{3}$ Other research using data collected before the crisis has discussed channels through which the current crisis may affect workers differently depending on their gender and occupation (Brussevich, Dabla-Norris, and Khalid, 2020; Mongey, Pilossoph, and Wienberg, 2020).
} 


\section{Data and Methodology}

We use the 2020 Edelman Trust Barometer Spring update conducted during the pandemic's first wave. The survey is obtained using standardized, representative individual-level data from 11 advanced and emerging countries, with detailed questions on perceptions of COVID-related economic risks, the role of government and other institutions. ${ }^{4}$ All fieldwork was conducted between April 15 and April 23, 2020, at least three weeks after stringent containment measures were implemented in most countries in the sample. Each country has around 1,200 observations. All data is nationally representative based on age, region, gender, and additionally in the UK and U.S. by race/ethnicity.

The survey contains information on basic demographic variables of respondents, education, their income quartile (although income and education are not nationally representative for the emerging market countries in the sample, see Table I), occupational characteristics (sector of work, employment status, size of firm worked), their self-reported subjective assessments of the government's policy responses to the COVID-19 pandemic, perceptions of the future, and expectations of government's role in dealing with the crisis.

\section{Assessment of government performance}

The satisfaction with government response to the pandemic is assessed using three measures: Overall, Health and Economy. All measures are defined on an index from 1 to 5, with higher index values indicating a more favorable assessment. The Overall measure captures responses to the statement, "Meeting your overall expectations of how the government should be responding", the Health measures the response to "Ensuring that medical supplies and good quality medical treatment are available even in the poorest areas", the Economy measure is for the statement "Taking the necessary actions to keep the economy from collapsing". Figure 1 reports a summary of respondents' views on government performance by individual characteristics.

Overall, 46 percent of respondents believed that the government was doing "well" or "very well" in meeting their expectations in handling the crisis. Respondents in Japan had the lowest perceptions of government responses while respondents in Saudi Arabia and India had the most favorable perceptions. Unemployed respondents, women, the less educated, and those working in firms with fewer than 100 employees all significantly held less favorable views of their government performance relative to their respective comparator groups (Figure 1). Urban and young (below 30 years) respondents, and those in tele-workable jobs (using the sector-level measure from Brussevich, Dabla-Norris, and Khalid, 2020) reported more favorable assessments of government responses. With the exception of South Korea and Saudi Arabia, there was

\footnotetext{
${ }^{4}$ The survey included 13,200 respondents in 11 countries: Canada, China, France, Germany, India, Japan, South Korea, Mexico, Saudi Arabia, UK and the U.S. Summary statistics of individual covariates are in the Annex.
} 
generally a more favorable perception of government responses on the economic compared to the health front. ${ }^{5}$

\section{Figure 1: Individual Characteristics and Overall Government Performance}

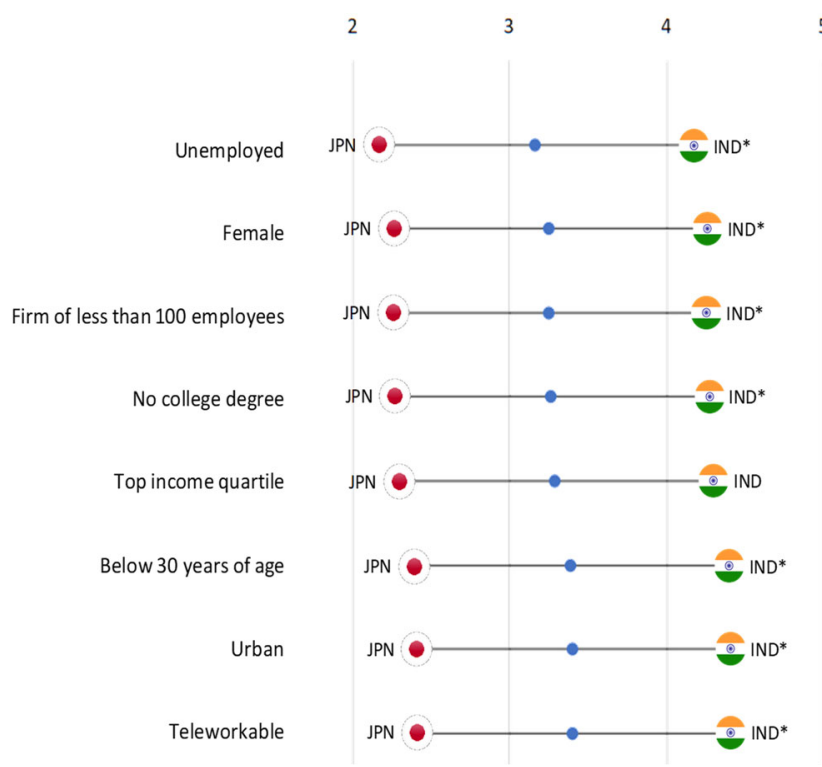

Source: Edelman Trust Barometer, Spring 2020.

Note: Blue dots represent weighted average of the whole sample to the response on Overall performance of government (rated 1-5) by different socio-demographic characteristics. End points represents countries with smallest and largest average concerns for that demographic characteristic. Each individual characteristic variable takes on values 0 or 1 , indicating that an individual belongs to that group. * indicates statistically significance at 1 percent significance level in relation to the comparator group.

\section{Support for the poor and concerns about the future}

We use responses on four measures to capture support for the poor and subjective concerns about the future: Vulnerable more affected, Capitalism is harmful, Prolonged job losses and Threat of automation. All measures are defined on an index from 1 to 9 , with higher values indicating a stronger agreement with the corresponding statement:

1) Vulnerable more affected: "Those with less education, less money and fewer resources are being unfairly burdened with most of the suffering, risk of illness, and need to sacrifice due to the pandemic."

2) Capitalism is harmful: "Capitalism as it exists today does more harm than good in the world."

3) Prolonged job losses: "I am very concerned about job loss due to the pandemic and not being able to find a new job for a very long time."

\footnotetext{
${ }^{5}$ Differences between the assessment of Health and Economy are statistically significant for all countries, with the exception of India and Saudi Arabia. China was not surveyed on the assessment of government performance.
} 
4) Fear of automation: "I worry that the pandemic will accelerate the rate at which companies move to replace human workers with Al and robots."

Overall, 67 percent of respondents believe that those with less education, less money and fewer resources are bearing an unfair burden of the suffering, risk of illness and need to sacrifice in the pandemic. More than half the respondents were worried about long-term, COVID-related job losses and the threat from automation. Further, more than half the respondents shared an unfavorable view of capitalism.

While a majority of the respondents believed that the vulnerable are disproportionately impacted by COVID-19, the unemployed, college-educated and high-income individuals reported greater concern relative to their respective comparator groups. The unemployed and young also displayed greater anxiety about prolonged job losses (Figure 2). Urban residents were generally the more anxious across all four dimensions, while those working in small firms are relatively less pessimistic. Respondents in emerging markets, on average, appeared to be more pessimistic compared to respondents in advanced economies, particularly in China and Mexico. Interestingly, respondents in Germany were less pessimistic about prolonged job losses given early measures implemented to alleviate the employment impact of the crisis.

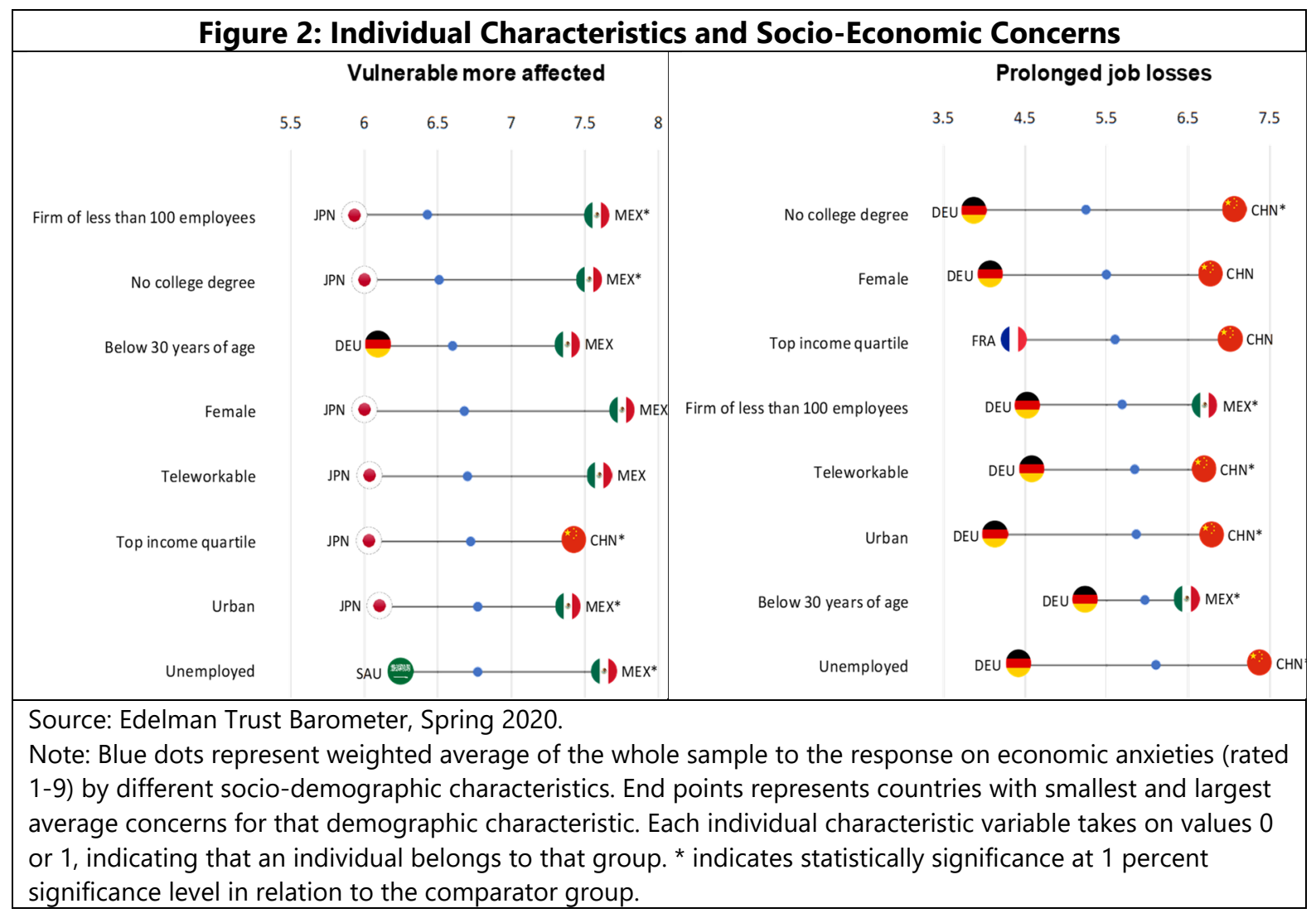

CInternational Monetary Fund. Not for Redistribution 


\section{Policy Preferences}

Finally, we examine responses to expectations of government's role in addressing the economic and health aspects of the crisis. These responses were recorded as a binary for each topic, with 1 indicating "Yes" for expectation for a leading role in the response and 0 being "No" expected involvement. We focus on the following subjects:

1) Give Financial relief: "Giving financial relief and support to people who have lost their jobs or livelihood"

2) Help small businesses: "Helping small businesses survive until they can reopen"

3) Manage the spread: "Develop and put in place the necessary policies and procedures to slow and control the spread of the virus"

4) Prep for reopening: "Plan and prepare for how the country will get back to normal after the worst of the pandemic is over."

The majority of respondents expect their governments to take a leading role in providing economic relief and support for affected businesses and individuals while controlling the spread of virus and planning for reopening the country. Compared to their counterparts, less educated, urban, tele-workable individuals, and respondents working in small firms expect the government to play a critical role in providing liquidity support and managing the virus spread (Figure 3 ). The young are significantly less supportive of government interventions.

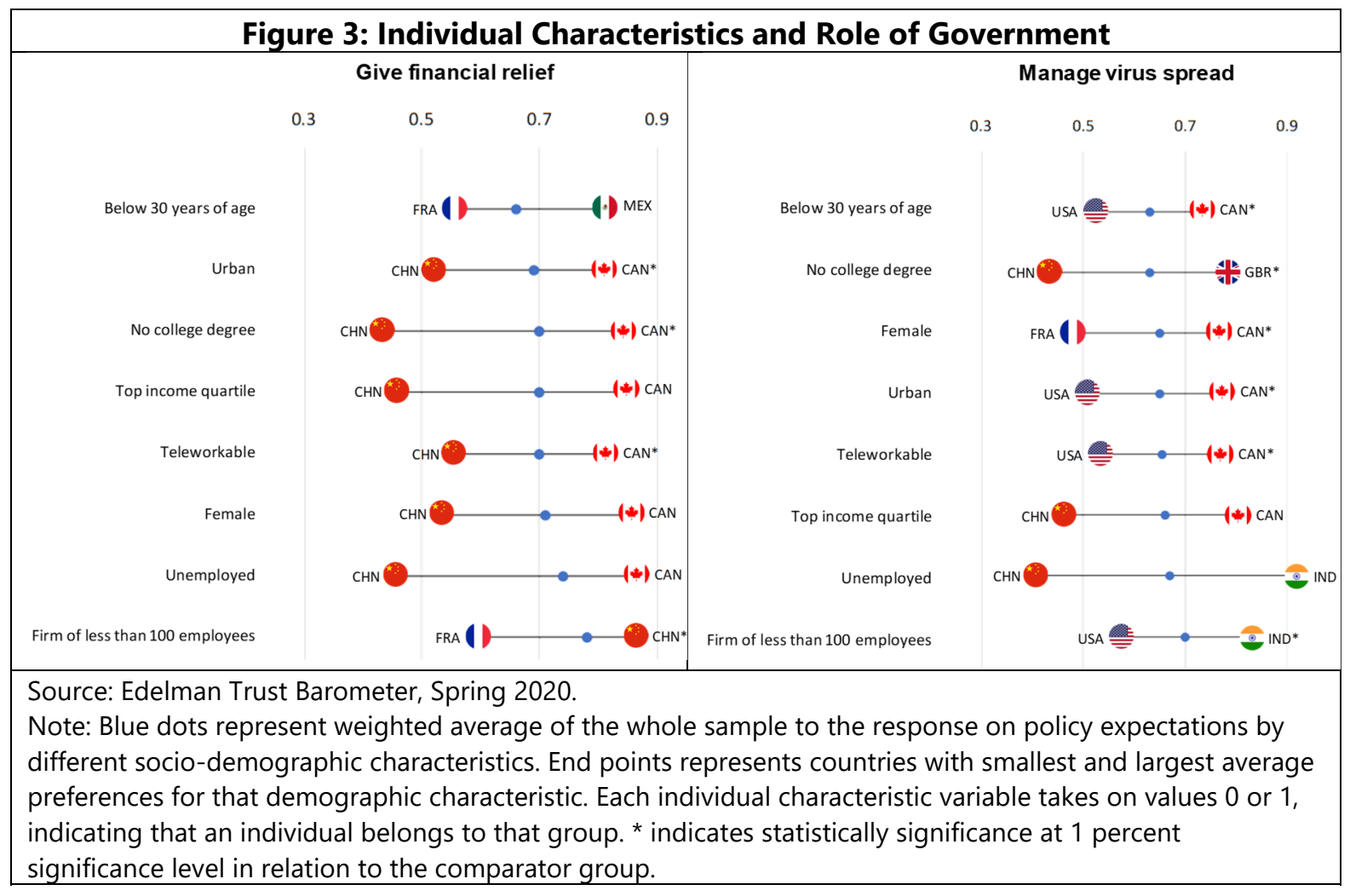




\section{Empirical Approach}

To formally investigate the relationship between demographic and occupational characteristics and perceptions of government performance and preferences for redistribution, we use a simple fixed effects linear probability model:

$$
Y_{i c}=\beta_{0}+\beta_{1} X_{i c}^{d}+\beta_{2} X_{i c}^{o}+\gamma_{c}+\varepsilon_{i c}(1)
$$

where $Y_{i c}$ is the outcome variables of interest, including assessment of government performance, concerns about the future, and policy preferences. The outcome variables are originally categorical values and are converted to binary indicators. ${ }^{6} X_{i c}^{d}$ includes individual demographic and socio-economic covariates and $X_{i c}^{o}$ are occupational characteristics. Coefficient of interests include $\beta_{1}$ and $\beta_{2} \cdot \gamma_{c}$ are country fixed effects to control for differences across countries. All regressions are weighted by the general public weights provided in the survey and errors are clustered at the country level.

Our first set of controls represents demographic and socio-economic variables. These include a dummy variable that equals 1 for female and 0 otherwise; age, where young is an indicator that equals 1 for respondents younger than 30 years old and 0 otherwise; and education, captured by a college indicator that equals 1 for at least college educated and 0 otherwise. Finally, we control for household income, where rich is a dummy that equals 1 for household income above the $75^{\text {th }}$ percentile and 0 otherwise.

The second set of controls captures occupational information for a sub sample of working-age individuals. This includes an unemployed dummy that equals 1 for unemployed respondents and 0 otherwise. Another indicator captures the "tele-workability" of the sector using data from Brussevich, Dabla-Norris, and Khalid (2020). Here, tele-workability is a dummy that equals 1 for sectors above the median in ability to work from home, and zero otherwise. We also control for firm size with a small firm indicator that equals 1 for being employed in a firm with less than 100 employees.

To identify the effects of being directly impacted by the COVID-19, we exploit two measures in the survey. First, the survey asks if respondents were infected or knew someone close infected by COVID-19. This captures the health impact of the crisis. The survey also identifies those who lost their job or were furloughed due to the COVID-19, which can be used identify the views of those economically affected by the crisis.

Preferences for redistribution and beliefs about the government's role are also a product of history, culture, and other country-specific characteristics. For instance, societies that prefer an equal distribution of income tend to choose larger, more redistributive governments. In addition,

${ }^{6}$ For government assessment, the outcome variable is a dummy that equals one for "agree" or "strongly agree" to the government meeting expectations, i.e. at least 4 on a scale of 5 . For concerns about the future, the outcome variable is a dummy that equals one for responses that are at least rated 7 out of 9 . For policy preferences, the response is already a dummy. 
countries chose various approaches to contain the virus and were at different stages of the crisis. To capture the role of underlying macroeconomic conditions and country-specific factors in shaping these views, we consider heterogeneity by country-level variations $\theta_{c}$ in the stringency of COVID-19 containment measures, trends in COVID-19 caseloads, and the initial level of inequality (equation 2).

$$
Y_{i c}=\beta_{0}+\beta_{1} X_{i c}^{d} \theta_{c}+\beta_{2} X_{i c}^{o} \theta_{c}+\gamma_{c}+\varepsilon_{i c}(2)
$$

Specifically, the dummy $\theta_{c}$ takes the value of 1 if the country is above the sample median in the Stringency Index from Oxford Covid-19 Government Response Tracker (Hale et al., 2020), if the country experienced an early surge in cases and the number of COVID-19 infections were on a declining trend during the time of survey, and if the country is above the sample median in the Gini Index, and 0 otherwise. We also create dummies for advanced and emerging economies and interact with each individual variable to shed light on the role of economic development.

\section{Results}

\section{Assessment of Government Performance}

We start our analysis by examining the perceptions of government responses to COVID-19. Tables 2-3 report the results of individual characteristics based on equation (1), while Tables 4-7 examine the role of country characteristics based on equation (2).

Gender: We find that women. on average, have a less favorable assessment of government performance along all three dimensions, overall, health, and economic (Table 2, Columns 2-6). This result is negative and statistically significant, and likely reflects the disproportionate impact of the crisis on women in many countries. ${ }^{7}$ Importantly, this gender gap persists even if we control for job characteristics (employment, part-time work, tele-workability), indicating that other factors indeed play a role. Using the decomposition methodology proposed by Gelbach (2016), we find that the estimated gender gap is robust to the inclusion of additional covariates, but about 7 percent of the gap can be explained by household income. Specifically, women in richer households have a more favorable assessment of the government's performance compared to respondents in poor households. Less favorable perceptions of government responses by women are particularly pronounced in advanced economies (Figure 4, Table 4).

\footnotetext{
${ }^{7}$ Adams-Prassl et al. (2020a) find a large gender gap in respondents' ability to work from home using surveys conducted in April. In the US, for instance, women on average report they can do 42 percent of their tasks from home, compared to 53 percent for men.
} 


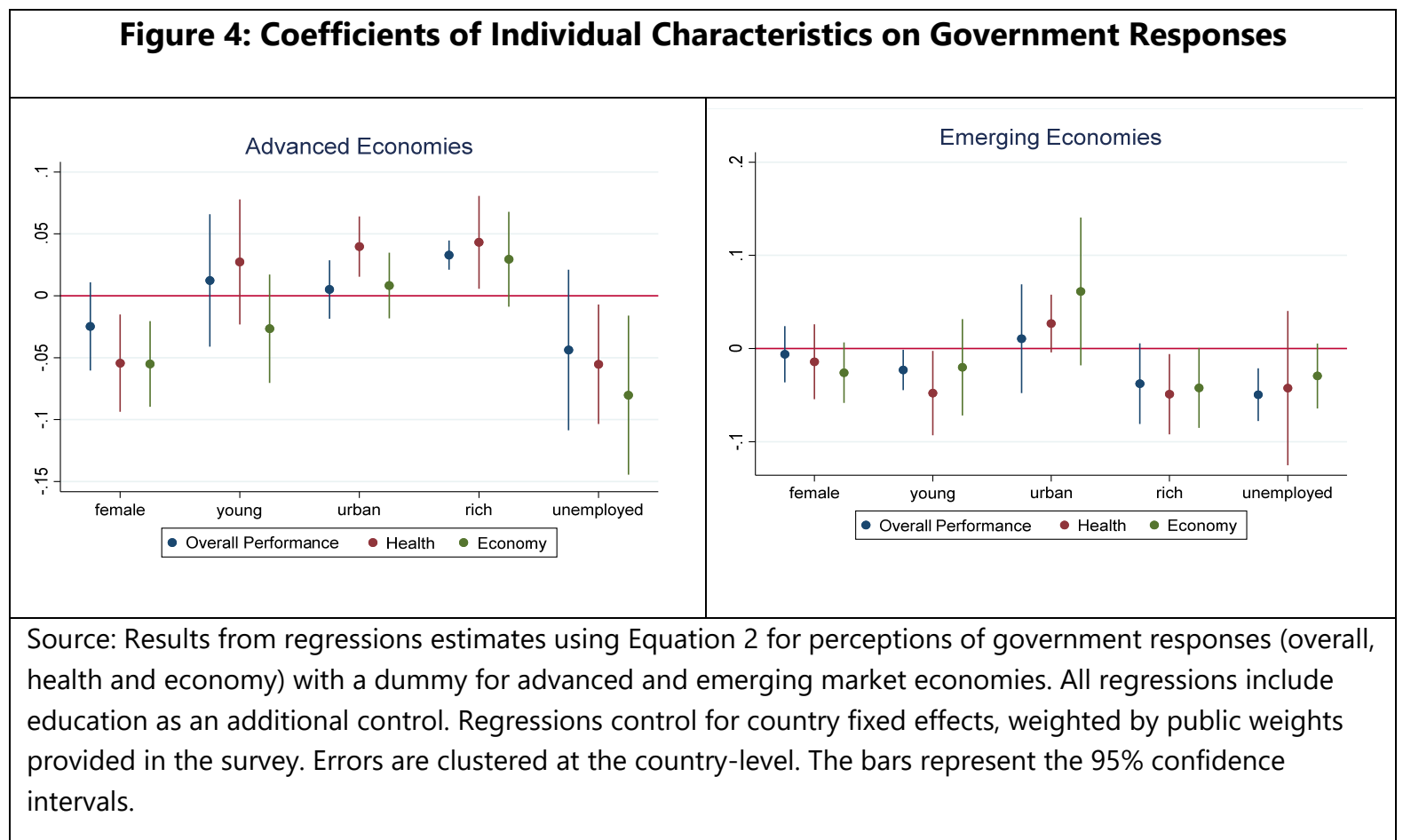

Employment: Unemployed individuals have less favorable perceptions of government performance. Specifically, controlling for the basic individual determinants in column 2 of Table 2, we find those that lost their jobs due to the COVID-19 crisis had less favorable perceptions of government performance in dealing with the health crisis (Table 3). Similarly, those employed in small firms have a less favorable view of the government in dealing with the health crisis. SMEs, particularly in retail and services sectors, have been significantly burdened by the COVID-19 crisis, potentially explaining the unfavorable assessment by workers in such firms. Individuals employed in tele-workable sectors have a more favorable view of the government's overall response as they are less likely to be economically impacted by the COVID-19 crisis in the first place.

Education: Even after controlling for income, education enters with a significant and positive coefficient: more educated individuals have a more favorable view of government performance with regards to the economy. But around 50 percent of the gap between college-educated and non-college educated individuals is explained by household income.

Income: Controlling for education and other demographic and occupational characteristics, perceptions of government performance by income are not statistically significant in the baseline regressions. However, we find that the rich have a more favorable assessment of the government in advanced economies (Table 4, Column 1-2; Figure 4). This is not surprising as lower-income respondents are more likely to lose their job or some portion of their income due to the pandemic and are also less likely to be able to work from home. The favorable assessment of government performance by richer respondents is not shared in emerging market economies. Note that emerging markets in our sample did not have a representative survey in terms of 
income, which suggests that the results for these countries need to be interpreted with caution. We also find that the rich are more approving of government performance in countries where less stringent measures were adopted, (Table 5). However, this result is negative and statistically significant in countries with higher initial levels of inequality (Table 7).

\section{Support for the Poor and Concerns about the Future}

Tables 8-9 and Figure 5 report the results for individual characteristics based on equation (1), while Tables 10-13 report the role of country characteristics in shaping individual concerns.

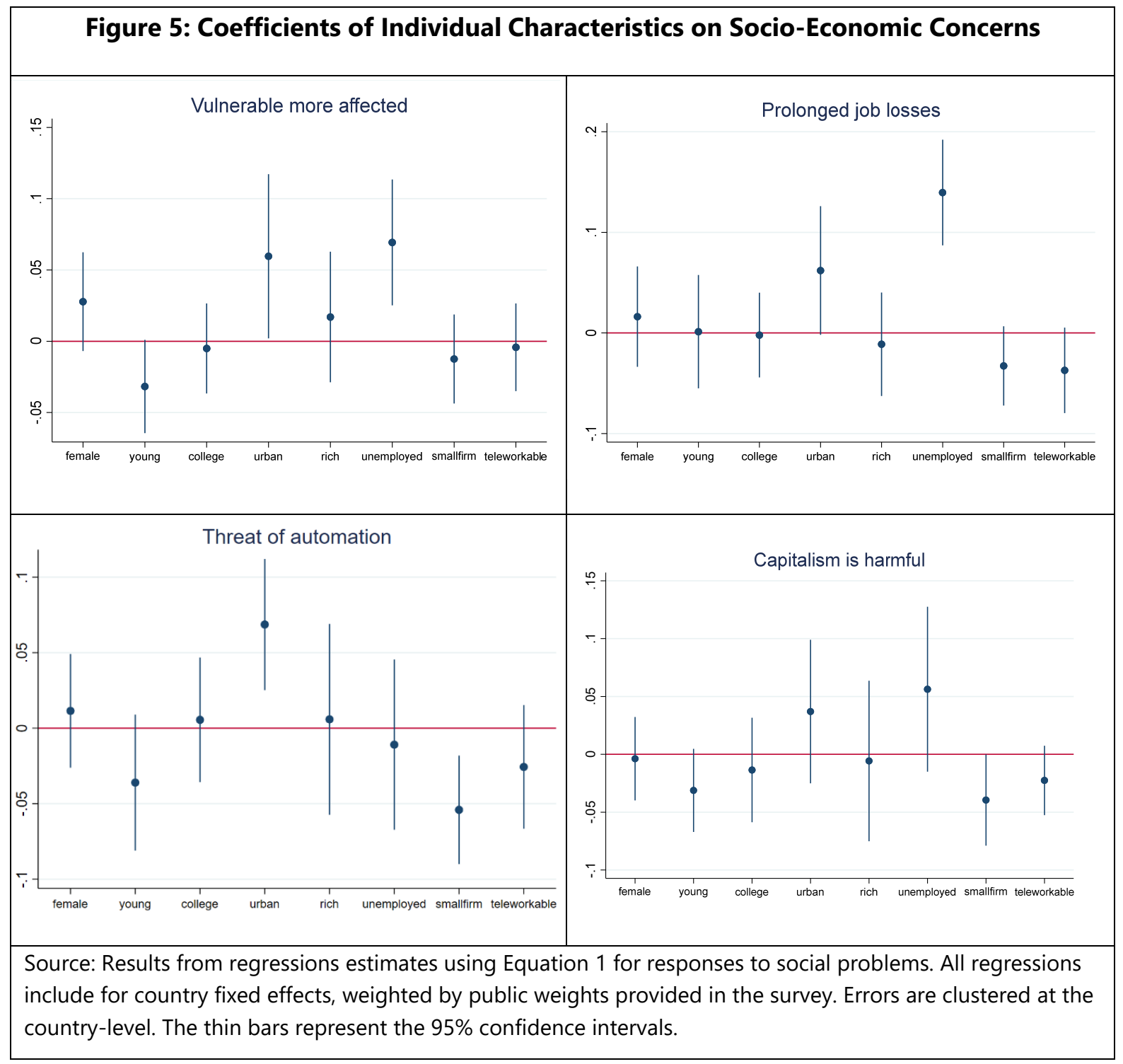

Gender: Women are more likely to believe that the vulnerable are more affected by the COVID19 crisis (Table 8, Column 1). However, this effect disappears once we control for the ability to tele-work in the sample of working age population. In countries where more stringent containment measures were in place at the time of the survey, women report heightened 
economic anxieties about the future, particularly concerns about prolonged job losses (Table 11). These results are consistent with women wearing the brunt of the adverse employment impact of lockdowns.

Age: Older individuals, who face higher infection risks, are more likely to believe that the vulnerable are more affected by COVID, view capitalism as being harmful, and be more concerned about the threat of automation relative to the young (Figure 5; Table 8). This is consistent with Bui et al. (2020) who shows that older workers over the age of 65, especially older women, are facing higher unemployment in the COVID-19-induced recession compared to previous ones. In emerging market economies, older people are also more likely to report concerns about prolonged job losses (Table 10). Economic anxieties of older respondents are also heightened in countries which saw a surge in cases early in the pandemic (Table 12), suggesting that recent adverse experiences can color people's perspectives about the future.

Personally affected: Even after controlling for other demographic characteristics, individuals that have been personally affected by the COVID-19, either suffered a job loss or have been exposed to infections, are more likely to have a more sympathetic attitude toward the vulnerable and report a more bleak outlook toward the future (Table 9). The results are positive and statistically significant across all socio-economic concerns.

Employment: As in the case of individuals directly impacted by the pandemic, the unemployed more broadly are more concerned about prolonged job losses, indicating that they expect the downturn to have persistently negative labor market impacts (Figure 5; Table 8). Interestingly, these economic anxieties are amplified for unemployed respondents in countries which saw an initial surge followed by a downward trend in COVID-19 cases at the time of the survey (Table 12). People working in the tele-workable jobs are generally less worried about automation and prolonged job losses. Surprisingly, respondents employed in small firms are also overall less pessimistic. This is despite the evidence of significant impact of COVID-19 crisis on SMEs (Kalemli-Ozcan et al., 2020; Bartik et al., 2020).

Education: Education alone does not appear to have a statistically significant impact on attitudes about the future once other socio-demographic characteristics are controlled for (Figure 5; Table 9). However, college educated individuals are less anxious about job losses and the threat of automation in countries where COVID-19 cases were already on a downward trend at the time the survey was conducted (Table 12).

Urban: We consistently find that urban residents are more pessimistic about the future (Figure 5, Table 9). This pessimism could be partly driven by urban areas facing the brunt of stringent containment measures in the initial stages of the pandemic.

Income: We find no statistically significant relationship between income and concerns about the future in the baseline regression reported in Table 8. However, richer households are generally less pessimistic about the future in advanced economies (Table 10). 
Overall, we see that economic anxiety was already amplified early on in the crisis, particularly amongst the economically vulnerable such as the unemployed, those in non-tele-workable jobs, and those experiencing illness or job loss caused by the pandemic. ${ }^{8}$

\section{Policy preferences}

Tables 14-16 and Figure 6 report baseline results on individual determinants of preferences for redistribution and the government's role in managing the pandemic, while Tables 17-20 examine how these preferences vary depending on country characteristics. The baseline regressions (Table 14) show that differences across gender and income are not statistically significant in terms of preferences for government support for households and firms, managing the spread of the virus or preparing the economy for reopening (a positive coefficient means a higher preference for government redistribution and government intervention in the economy).

Age: Consistent with older people being more anxious about social problems, we find that they tend to favor financial support for households and small businesses compared to the young (Figures 5-6). These results are positive and significant and are consistent with trends noted in Ashok et al. (2015), whereby the elderly have grown more supportive of redistribution policies relative to other groups in developed countries. This result is also consistent with the extensive literature based on answers to surveys (see the review by Alesina and Giuliano, 2011), which shows that people who believe that the poor are unfortunate are much more likely to support redistributive policies. Interestingly, the young favor a role for government in providing relief to affected individuals in emerging market economies compared to advanced economies (Table 16).

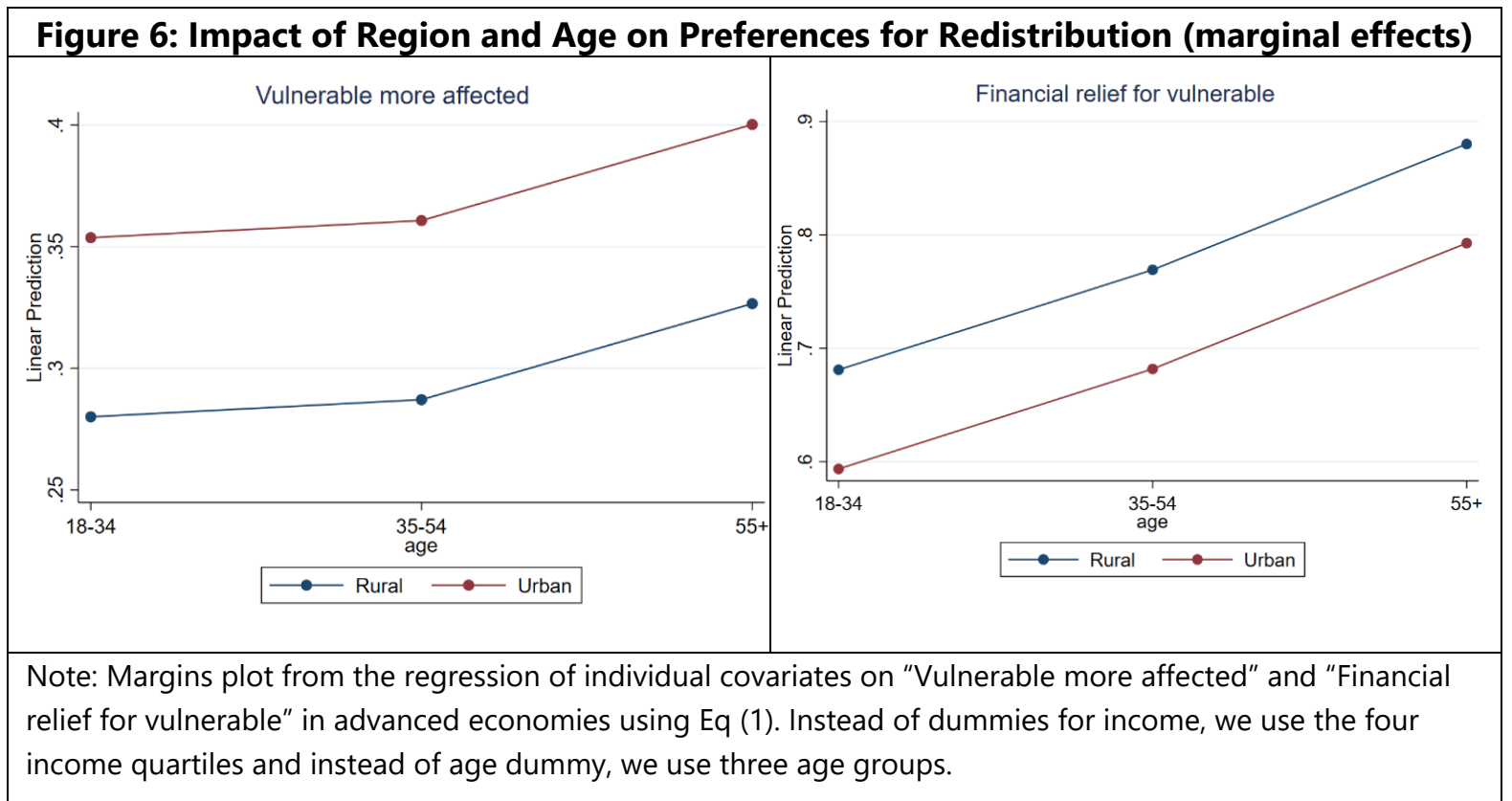

\footnotetext{
${ }^{8}$ These results are robust to controlling for the assessment of government performance (results not reported, but available upon request), which does not have a significant relationship with concerns about social problems.
} 
Personally affected: A history of misfortune in the recent past can change people's views of redistribution. We explore this effect in Table 15. As always, we control for the basic individual determinants of column 1 of Table 2 . While we find no statistically significant result for government support among those who suffered a job loss on account of the pandemic, and the effect is negative and statistically significant for those who suffered an adverse health impact. ${ }^{9}$ This could be interpreted as the crisis making them more risk-averse and less optimistic about the government's role.

Employment: The unemployed are keen on the government preparing for reopening, consistent with their concerns that COVID-19 could result in prolonged job losses (Table 14, Column 7), but we find no statistically significant relationship between being unemployed and preferences for supporting vulnerable households and firms. Individuals working in small firms exhibit more support for financial relief, including helping small businesses until they can reopen (Table 14). Individuals working in tele-workable jobs express more support for government role in managing the crisis, specifically in providing liquidity support for those impacted by the crisis.

Urban: Urban residents are less supportive of government interventions, although they are more concerned about social problems (Table 14, Figure 6). This is in line with Sands (2017) who shows that exposure to socioeconomic inequality in an everyday setting can negatively affect willingness to publicly support redistributive economic policies. This relationship reverses in emerging markets and in countries with more stringent lockdowns where urban respondents were likely to be more economically impacted themselves (Table 19-20). Using the decomposition method proposed by Gelbach (2016), we breakdown the role of individual covariates in explaining the difference between urban and rural respondents in advanced economies. Being young reduces the negative relationship between urban residence and government provision of financial support by 10 percent. Being in a tele-workable profession weakens the relationship by an additional 5 percent. However, much of the urban-rural divide is unexplained by the individual covariates.

Income: Interestingly, individuals with higher household incomes are more likely to support social safety nets and liquidity support for the economically vulnerable (Figure 7). While the rich dummy does not yield significant results in the baseline regressions reported in Table 14, we find a significant positive effect for households in the upper two quartiles and middle two quartiles. This is in line with the extensive experimental literature which shows that preferences for redistribution may be dictated by a sense of fairness or aversion to inequality (see Durante, Putterman and Van der Weele, 2014; Cowell and Schokkaert, 2001).

\footnotetext{
${ }^{9}$ This is in contrast to Margalit (2013) who finds that personal experience of economic hardship, particularly the loss of a job, had a major effect on increasing support for welfare spending during the Great Recession. Our results highlight the unique nature of the COVID-19 crisis and could partly be attributed the unprecedented fiscal response in many countries. In fact, Margalit (2013) also finds that personal experience of an economic shock has a sizable yet overall transient effect on policy preferences.
} 


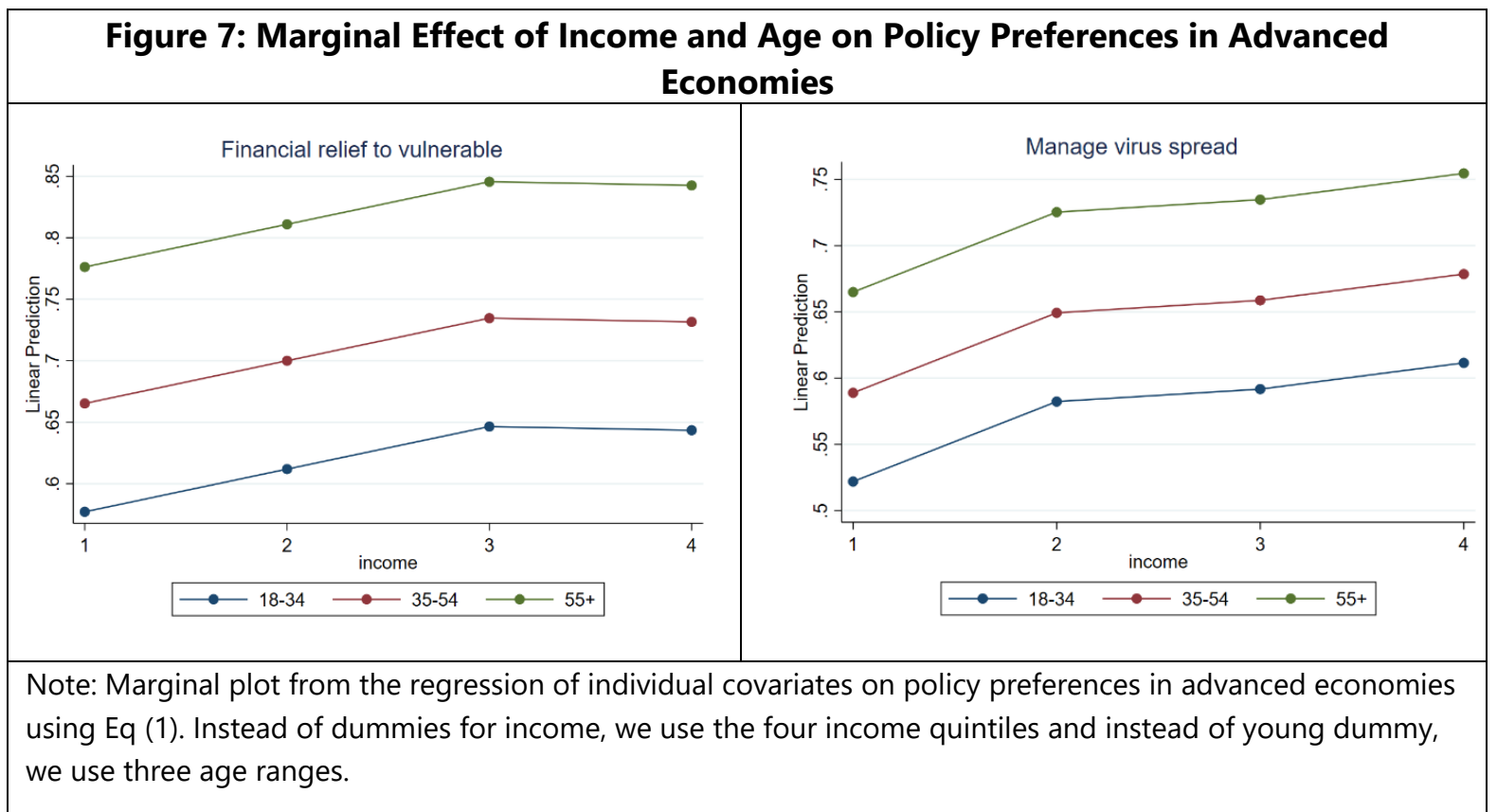

Perceptions of government performance: Finally, controlling for demographic and occupational characteristics, individuals who have a more favorable assessment of government performance also expect the government to continue to take a leading role in offering liquidity support, addressing the health crisis and preparing for reopening (Table 18). The size of the government performance coefficient estimates is fairly stable across specifications, and only partially explained by the inclusion of the other variables. This is consistent with Algan et al. (2015) who show that public trust in government has a positive influence on the size of the welfare state.

\section{Robustness Checks}

Our results are robust to a battery of robustness checks. Using the Gelbach (2016) decomposition, we find that the estimated coefficients on the variables of interest are generally robust even after additional covariates are partialled out. While a linear probability specification is used for the main analysis, the results are broadly robust to using probit (Tables 21-23). Since the surveys in emerging economies are not always representative, we check the consistency of our results focusing only on advanced economies. We find that our results on individual determinants are broadly robust to exclusion of respondents from emerging market economies (Table 24-26).

Many Asian countries (e.g., China, Japan, South Korea) saw a surge in infections earlier than in Western and Northern Europe and have weaker automatic stabilizers, which could have a bearing on preferences for redistribution and the role of government. To test whether our results on individual determinants are robust to exclusion of these countries, we estimated the regressions excluding these countries (Tables 27-29). Overall, the results are broadly consistent but concerns about prolonged job losses and threat of automation are not as statistically significant in the truncated sample. 
In China, respondents were not surveyed on the assessment of government performance. In Saudi Arabia, while respondents were surveyed, the responses had gaps. We test the robustness of our results dropping these two countries. Our results remain robust to this exclusion (not reported here but available upon request).

The Edelman Survey has additional questions on the assessment of government that capture the health and economic response of the government. For economic, we use the responses to "Taking care of people who are suffering pandemic-related financial hardships" and for health, "Creating a distribution system that ensures that medical and other necessary supplies are getting to where they are needed most." For policy preferences, we use the following alternatives to capture the economic support and preparation for reopening, respectively: "Keeping the country's economy running as well as possible" and "Guidelines for when it is okay to start relaxing social distancing requirements so that people can begin returning to work, schools can be reopened, and people can start to engage in group activities again". Using alternative measures (results available upon request) also yields consistent results. Finally, we include additional covariates such as part-time work. There are no significant differences between parttime and full-time employees once other individual characteristics are controlled for.

\section{Conclusion}

We use an individual-level survey for 11 advanced and emerging market economies to empirically examine perceptions of government responses in managing the health and economic fallout of COVID-19, beliefs about the future, and preferences for the government's role in containing the crisis.

Our results show that perceptions about how well the government has handled the crisis depend on individual characteristics such as gender, age, region, employment and socio-economic status, but they are also a product of recent experiences with adversity. Importantly, our analysis suggests that the economically vulnerable and those hardest hit by the crisis had a much less favorable view of government responses during the early months of the pandemic. We also find evidence that experiencing serious illness or job loss caused by the pandemic can shape people's beliefs about the future, heightening concerns about prolonged job losses, and the imminent threat from automation. This suggests that policy measures that directly reduce economic hardship and anxiety are essential to contain the fallout from the pandemic. Economic anxieties were heightened in countries that experienced an early surge in infections followed by successful containment, suggesting that negative beliefs can persist.

Overall, we find support for direct transfers that alleviate economic hardship in the short term and stabilize the economy. Such programs have already been deployed in many advanced and emerging market economies. Support for pro-equality redistributive policies varies, depending on personal experiences and views about the poor. Importantly, preferences for providing financial support to individuals and firms hit hardest by the crisis are also related to whether individuals held a favorable perception of government performance, highlighting the importance of effective containment policies on the health and economic front. 
Our analysis is restricted to a single time period relatively early on in the crisis. While we study cross-country heterogeneity based on the stringency of containment measures and timing of surges in COVID-cases, most countries in our sample were dealing with the first wave of infections. Many countries have since had multiple waves, with repeat lockdowns. In addition, countries have deployed large policy packages to smooth the impact on the economically vulnerable. Therefore, the identified relationships, beliefs and preferences could change over time. Further research and the availability of longer panel datasets on attitudes and preferences for redistribution during COVID-19 are needed to better pin down these effects.

Finally, our analysis using survey data has limitations that are common to such studies. The framing of questions on policy preferences can result in different conclusions. For example, the question on financial support for the economically vulnerable and businesses does not include implications of higher taxation in the future. Daniele et al. (2020) find less support for welfare spending through higher taxation whereas Klemm and Mauro (forthcoming) show that those personally affected by the crisis are more supportive of progressive taxation. Self-reported subjective assessments can also be subject to altruism bias that can skew the findings. Given that our results are generally in line with those economically impacted by the crisis responding differently, such concerns are partially alleviated. 


\section{References}

Adams-Prassl, Abigail, Teodora Boneva, Marta Golin, and Christopher Rauh. 2020a. "Inequality in the Impact of the Coronavirus Shock: Evidence from Real Time Surveys." IZA DP No. 13183.

Adams-Prassl, Abigail, Teodora Boneva, Marta Golin, and Christopher Rauh. 2020b. "The Impact of the Coronavirus Lockdown on Mental Health: Evidence from the US," Working Papers 2020-030, Human Capital and Economic Opportunity Working Group.

Algan, Yann, P. Cahuc and M. Sangnier. 2015. "Trust and the Welfare State: The Twin Peaks Curve." The Economic Journal 126(593): 861-883.

Algan, Y., G. Sergei, S., Papaioannou and E. Passari. 2017. "The European Trust Crisis and the Rise of Populism." Brookings Papers on Economic Activity: 309-382.

Alesina, Alberto, and Eliana La Ferrara. 2000. "Participation in Heterogeneous Communities." Quarterly Journal of Economics 115: 847-904.

Alesina, Alberto and Giuliano, Paola. 2011. "Preferences for Redistribution." Handbook of Social Economics, A Bisin and Benhabib, J, 93-132. North Holland.

Alesina, Alberto, Stefanie Stantcheva, and Edoardo Teso. 2018. "Intergenerational Mobility and Preferences for Redistribution." American Economic Review 108(2): 521 - 554.

Alon, Titan M, Matthias Doepke, Jane Olmstead-Rumsey, and Michele Tertilt. 2020. "The Impact of COVID-19 on Gender Equality." Working Paper 26947. National Bureau of Economic Research.

Bartik, Alexander W., Marianne Bertrand, Zoë B. Cullen, Edward L. Glaeser, Michael Luca, and Christopher T. Stanton. 2020. "How Are Small Businesses Adjusting to COVID19? Early Evidence from a Survey." NBER Working Paper 26989.

Binder, Carola. 2020. "Coronavirus Fears and Macroeconomic Expectations." Review of Economics and Statistics: forthcoming.

Brodeur, A., Grigoryeva, I., \& Kattan, L. 2020. "Stay-at-Home Orders, Social Distancing and Trust." IZA Discussion Paper No. 13234. Institute of Labor Economics.

Brück, T., Ferguson, N., Justino, P., \& Stojetz, W. 2020. "Trust in the Time of Corona." IZA Discussion Paper No. 13386. Institute of Labor Economics.

Brussevich, Maria Era Dabla-Norris and Salma Khalid. 2020. "Who will Bear the Brunt of Lockdown Policies? Evidence from Tele-workability Measures Across Countries." IMF Working Paper WP/20/88. 
Bui, T. T. M., Button, P., \& Picciotti, E. G. 2020. "Early Evidence on the Impact of COVID-19 and the Recession on Older Workers." NBER Working Paper No. 27448. National Bureau of

Christian, Cornelius, Lukas Hensel, and Christopher Roth. 2019. "Income Shocks and Suicides: Causal Evidence From Indonesia." Review of Economics and Statistics 101(5): 905-920.

Cowell, Frank and Erik Schokkaert. 2001. "Risk Perceptions and Distributional Judgments." European Economic Review 45(4): 941-952.

Coibion, O, Y Gorodnichenko and M Weber. 2020. "The Cost of the COVID-19 Crisis: Lockdowns, Macroeconomic Expectations, and Consumer Spending." BFI Working Paper 2020-60.

Era Dabla-Norris, Frederico Lima and Hibah Khan. "What Determines Social Distancing? Evidence from Advanced and Emerging Market Economies." IMF Working Paper (forthcoming).

Daniele, Gianmarco, Andrea F.M. Martinangeli, Francesco Passarelli, Willem Sas, Lisa Windsteiger. 2020. "Wind of Change? Experimental Survey Evidence on the COVID-19 Shock and Socio-Political Attitudes in Europe." CESifo Working Paper No. 8517.

Durante, Ruben, Louis Putterman and Joël J. Van der Weele. 2014. "Preferences for Redistribution and Perception of Fairness: An Experimental Study." Journal of the European Economic Association, vol. 12(4), pages 1059-1086.

Fetzer, T, L Hensel, J Hermle and C Roth. 2020. "Coronavirus Perceptions and Economic Anxiety." VoxEU.org, 21 March.

Gelbach, Johah. 2016. "When Do Covariates Matter? And Which Ones, and How Much?" Journal of Labor Economics 34(2): 509 - 543.

Giuliano, Paola and Spilimbergo. Antonio. 2014. "Growing Up in a Recession." The Review of Economic Studies 81(2): 787-817.

Gozgor, Giray. 2020. "Global Evidence on the Determinants of Public Trust in Governments During the COVID-19." CESifo Working Paper No. 8313.

Hanspal, Tobin, Annika Weber and Johannes Wohlfart. 2020. "Exposure to the COVID-19 Stock Market Crash and its Effect on Household Expectations." CEBI Working Paper Series, No. $13 / 20$.

Haushofer, Johannes and Jeremy Shapiro. 2016. "The Short-term Impact of Unconditional Cash Transfers to the Poor: Experimental Evidence from Kenya." The Quarterly Journal of Economics 131(4): 1973-2042.

International Monetary Fund (IMF). 2020. "Global Prospects and Policies." World Economic Outlook Chapter 1. October 2020. International Monetary Fund, Washington, DC. 
Kuziemko, llyana, Michael I. Norton, Emmanuel Saez and Stefanie Stantcheva. 2015. "How Elastic Are Preferences for Redistribution? Evidence from Randomized Survey Experiments." American Economic Review 105(4): 1478 - 1508.

Margalit, Yotam. 2013. "Explaining Social Policy Preferences: Evidence from the Great Recession." American Political Science Review 107(1): 80-103.

Klemm, Alexander, and Paolo Mauro. 2021. "Pandemics and Progressivity." IMF Working Paper (forthcoming).

Mongey, Simon, Laura Pilossoph, and Alex Wienberg. 2020. "Which Workers Bear the Burden of Social Distancing Policies?." CEPR Covid Economics 12.

Sands, Melissa. 2017. "Exposure to Inequality Affects Support for Redistribution." PNAS first published January 9, 2017; https://doi.org/10.1073/pnas.1615010113

Stevenson, Betsy and Justin Wolfers. 2011. "Trust in Public Institutions over the Business Cycle." American Economic Review 101(3):281-87. 


\section{Annex}

\section{Table 1: Summary Statistics of Individual Covariates by Country}

\begin{tabular}{|l|cc|cc|cc|cc|c|c|}
\cline { 2 - 11 } \multicolumn{1}{c|}{} & \multicolumn{3}{c|}{ Male } & \multicolumn{2}{c|}{ Median Household income } & \multicolumn{2}{c|}{ Unemployed } & \multicolumn{2}{c|}{ College - educated } \\
\hline \multicolumn{1}{c|}{ Country } & Sample & Population & Sample & Population & Sample & Population & Sample & Population & Sample & Population \\
\hline United States & 0.49 & 0.48 & 47 & 38 & 62566 & 64324 & 0.09 & 0.15 & 0.59 & 0.44 \\
Canada & 0.50 & 0.49 & 48 & 41 & 58439 & 61400 & 0.11 & 0.13 & 0.42 & 0.54 \\
China & 0.51 & 0.53 & 45 & 38 & 159900 & 40658 & 0.02 & 0.06 & 0.46 & 0.17 \\
Japan & 0.49 & 0.49 & 52 & 48 & 5461817 & 5602000 & 0.03 & 0.02 & 0.49 & 0.48 \\
South Korea & 0.50 & 0.50 & 48 & 44 & 42184810 & 45280934 & 0.04 & 0.04 & 0.67 & 0.45 \\
India & 0.52 & 0.52 & 37 & 27 & 514852 & 235275 & 0.03 & 0.24 & 0.82 & 0.11 \\
United Kingdom & 0.49 & 0.49 & 48 & 41 & 27635 & 30800 & 0.09 & 0.04 & 0.42 & 0.42 \\
Germany & 0.49 & 0.49 & 51 & 46 & 29290 & 27902 & 0.04 & 0.04 & 0.31 & 0.27 \\
France & 0.48 & 0.48 & 49 & 42 & 23378 & 21776 & 0.07 & 0.09 & 0.45 & 0.32 \\
Mexico & 0.49 & 0.48 & 38 & 29 & 146877 & 235226 & 0.08 & 0.05 & 0.70 & 0.19 \\
Saudi Arabia & 0.58 & 0.55 & 35 & 30 & 73877 & 93690 & 0.07 & 0.06 & 0.53 & 0.22 \\
\hline
\end{tabular}

Note: Mean/Median for the sample weighted by the survey weights.

Table 2: Assessment of Government Performance - Baseline

\begin{tabular}{|c|c|c|c|c|c|c|}
\hline & \multicolumn{2}{|c|}{ Overall } & \multicolumn{2}{|c|}{ Health } & \multicolumn{2}{|c|}{ Economic } \\
\hline & $(1)$ & (2) & (3) & (4) & $(5)$ & $(6)$ \\
\hline Female & $\begin{array}{l}-0.0218 \\
(0.0124)\end{array}$ & $\begin{array}{c}-0.0356^{* * *} \\
(0.0146)\end{array}$ & $\begin{array}{c}-0.0450 * * \\
(0.0150)\end{array}$ & $\begin{array}{c}-0.0577 * * * \\
(0.0175)\end{array}$ & $\begin{array}{c}-0.0503 * * * \\
(0.0126)\end{array}$ & $\begin{array}{c}-0.0479 * * * \\
(0.0145)\end{array}$ \\
\hline Young & $\begin{array}{r}-0.00236 \\
(0.0161)\end{array}$ & $\begin{array}{c}0.0173 \\
(0.0115)\end{array}$ & $\begin{array}{l}-0.00597 \\
(0.0219)\end{array}$ & $\begin{array}{l}0.00109 \\
(0.0258)\end{array}$ & $\begin{array}{c}-0.0252 \\
(0.0170)\end{array}$ & $\begin{array}{r}-0.00385 \\
(0.0170)\end{array}$ \\
\hline College & $\begin{array}{c}0.0136 \\
(0.0116)\end{array}$ & $\begin{array}{l}0.00902 \\
(0.0149)\end{array}$ & $\begin{array}{c}0.0177 \\
(0.0145)\end{array}$ & $\begin{array}{c}0.0167 \\
(0.0198)\end{array}$ & $\begin{array}{c}0.0144 \\
(0.0120)\end{array}$ & $\begin{array}{l}0.0341^{*} \\
(0.0180)\end{array}$ \\
\hline Urban & $\begin{array}{l}0.00621 \\
(0.0109)\end{array}$ & $\begin{array}{l}0.00826 \\
(0.0202)\end{array}$ & $\begin{array}{c}0.0399 * * * \\
(0.00921)\end{array}$ & $\begin{array}{c}0.0473 * * \\
(0.0183)\end{array}$ & $\begin{array}{c}0.0183 \\
(0.0146)\end{array}$ & $\begin{array}{c}0.0188 \\
(0.0258)\end{array}$ \\
\hline Rich & $\begin{array}{l}0.00656 \\
(0.0153)\end{array}$ & $\begin{array}{c}0.0196 \\
(0.0156)\end{array}$ & $\begin{array}{l}0.00875 \\
(0.0211)\end{array}$ & $\begin{array}{l}0.00948 \\
(0.0237)\end{array}$ & $\begin{array}{l}0.00353 \\
(0.0185)\end{array}$ & $\begin{array}{c}0.0104 \\
(0.0183)\end{array}$ \\
\hline Unemployed & $\begin{array}{c}-0.0469^{*} \\
(0.0215)\end{array}$ & $\begin{array}{l}-0.0290 \\
(0.0479)\end{array}$ & $\begin{array}{c}-0.0522^{* *} * \\
(0.0199)\end{array}$ & $\begin{array}{l}-0.0536 \\
(0.0312)\end{array}$ & $\begin{array}{c}-0.0689 * * \\
(0.0227)\end{array}$ & $\begin{array}{l}-0.0363 \\
(0.0414)\end{array}$ \\
\hline Small firm & & $\begin{array}{l}0.00157 \\
(0.0138)\end{array}$ & & $\begin{array}{l}-0.0423 * \\
(0.0201)\end{array}$ & & $\begin{array}{l}-0.0151 \\
(0.0223)\end{array}$ \\
\hline Tele-workable & & $\begin{array}{l}0.0249 * * \\
(0.00976)\end{array}$ & & $\begin{array}{c}0.0213 \\
(0.0150)\end{array}$ & & $\begin{array}{c}0.0135 \\
(0.0154)\end{array}$ \\
\hline Observations & 11,197 & 6,279 & 11,197 & 6,279 & 11,197 & 6,279 \\
\hline Country FE & Yes & Yes & Yes & Yes & Yes & Yes \\
\hline
\end{tabular}

Note: Results from Equation (1) where the dependent variable is an indicator that equals 1 for favorable assessment of the government performance (at least 4 on the scale of 1-5 in the survey). Errors are clustered at the country-level and regressions are weighted by public weights provided in the survey. ${ }^{* *} p<0.01,{ }^{* *} p<0.05$ and ${ }^{*} p<0.1$ 
Table 3: Assessment of Government Performance by Personally Affected

\begin{tabular}{lcccccc}
\hline & $(1)$ & $(2)$ & $(3)$ & $(4)$ & $(5)$ & $(6)$ \\
& Overall & Overall & Health & Health & $\begin{array}{c}\text { (5) } \\
\text { Economic }\end{array}$ & $\begin{array}{c}\text { Economic } \\
\text { Lost Job }\end{array}$ \\
& -0.0233 & & $-0.0553^{*}$ & & -0.0475 & \\
Infected & $(0.0440)$ & & $(0.0297)$ & & $(0.0395)$ & \\
& & 0.00528 & & 0.0282 & & -0.0134 \\
& & $(0.0198)$ & & $(0.0232)$ & & $(0.0246)$ \\
Observations & 11,197 & 11,197 & 11,197 & 11,197 & 11,197 & 11,197 \\
Individual controls & Yes & Yes & Yes & Yes & Yes & Yes \\
Country FE & Yes & Yes & Yes & Yes & Yes & Yes \\
& & & & & &
\end{tabular}

Note: Results from Equation (1) where the dependent variable is an indicator that equals 1 for favorable assessment of the government performance. Individual controls include gender, age, urban, education, employment status and household income dummies. Errors are clustered at the country-level and regressions are weighted by public weights provided in the survey. ${ }^{* * *} p<0.01,{ }^{* *} p<0.05$ and ${ }^{*} p<0.1$

\section{Table 4: Assessment of Government Performance - Advanced vs Emerging Market Economies}

\begin{tabular}{|c|c|c|c|}
\hline & $\begin{array}{c}(4) \\
\text { Overall }\end{array}$ & $\begin{array}{c}(5) \\
\text { Health } \\
\end{array}$ & $\begin{array}{c}(6) \\
\text { Economic }\end{array}$ \\
\hline Female & $\begin{array}{l}-0.0248 \\
(0.0161)\end{array}$ & $\begin{array}{c}-0.0544 * * \\
(0.0177)\end{array}$ & $\begin{array}{c}-0.0551 * * * \\
(0.0156)\end{array}$ \\
\hline Young & $\begin{array}{c}0.0123 \\
(0.0241)\end{array}$ & $\begin{array}{c}0.0273 \\
(0.0228)\end{array}$ & $\begin{array}{l}-0.0266 \\
(0.0198)\end{array}$ \\
\hline College & $\begin{array}{c}0.0157 \\
(0.0162)\end{array}$ & $\begin{array}{l}0.00717 \\
(0.0192)\end{array}$ & $\begin{array}{c}0.0118 \\
(0.0165)\end{array}$ \\
\hline Urban & $\begin{array}{c}0.00511 \\
(0.0106)\end{array}$ & $\begin{array}{c}0.0397^{*} * * \\
(0.0110)\end{array}$ & $\begin{array}{l}0.00827 \\
(0.0120)\end{array}$ \\
\hline Rich & $\begin{array}{c}0.0328 * * * \\
(0.00533)\end{array}$ & $\begin{array}{c}0.0432^{* *} \\
(0.0169)\end{array}$ & $\begin{array}{c}0.0295 \\
(0.0173)\end{array}$ \\
\hline Unemployed & $\begin{array}{l}-0.0438 \\
(0.0293)\end{array}$ & $\begin{array}{c}-0.0553^{* * *} \\
(0.0218)\end{array}$ & $\begin{array}{c}-0.0803^{* *} * \\
(0.0290)\end{array}$ \\
\hline Female x EM & $\begin{array}{c}0.0163 \\
(0.0254)\end{array}$ & $\begin{array}{c}0.0354 \\
(0.0307)\end{array}$ & $\begin{array}{c}0.0205 \\
(0.0235)\end{array}$ \\
\hline Young x EM & $\begin{array}{l}-0.0418 \\
(0.0258)\end{array}$ & $\begin{array}{c}-0.0851 * * \\
(0.0316)\end{array}$ & $\begin{array}{l}0.00357 \\
(0.0353)\end{array}$ \\
\hline College x EM & $\begin{array}{l}-0.0168 \\
(0.0198)\end{array}$ & $\begin{array}{c}0.0246 \\
(0.0194)\end{array}$ & $\begin{array}{l}0.00223 \\
(0.0198)\end{array}$ \\
\hline Urban x EM & $\begin{array}{l}0.00863 \\
(0.0398)\end{array}$ & $\begin{array}{l}-0.00264 \\
(0.0182)\end{array}$ & $\begin{array}{l}0.0776^{*} \\
(0.0394)\end{array}$ \\
\hline Rich x EM & $\begin{array}{c}-0.0847^{*} * k_{k} \\
(0.0223)\end{array}$ & $\begin{array}{c}-0.110^{* * *} * \\
(0.0235)\end{array}$ & $\begin{array}{c}-0.0877^{*} \text { * } k^{*} \\
(0.0260)\end{array}$ \\
\hline Unemployed x EM & $\begin{array}{c}-0.0126 \\
(0.0314)\end{array}$ & $\begin{array}{l}0.00669 \\
(0.0468)\end{array}$ & $\begin{array}{c}0.0459 \\
(0.0345)\end{array}$ \\
\hline $\begin{array}{l}\text { Observations } \\
\text { Country FE }\end{array}$ & $\begin{array}{c}11,197 \\
\text { Yes }\end{array}$ & $\begin{array}{c}11,197 \\
\text { Yes }\end{array}$ & $\begin{array}{c}11,197 \\
\text { Yes }\end{array}$ \\
\hline
\end{tabular}

Note: Results from Equation (2) where the dependent variable is an indicator that equals 1 for favorable assessment of the government performance and interaction term $E M$ is a dummy that equals 1 for emerging economics and 0 otherwise. Errors are clustered at the country-level and regressions are weighted by public weights provided in the survey. ${ }^{* *} p<0.01,{ }^{* *} p<0.05$ and ${ }^{*} p<0.1$ 
Table 5: Assessment of Government Performance by Stringency of Containment Measures

\begin{tabular}{lccc}
\hline & $(1)$ & $(2)$ & $(3)$ \\
& Overall & Health & Economic \\
\hline Female & & & \\
& -0.0279 & $-0.0620^{* * *}$ & $-0.0527 * *$ \\
Young & $(0.0184)$ & $(0.0190)$ & $(0.0183)$ \\
College & -0.00254 & 0.0113 & -0.0340 \\
& $(0.0224)$ & $(0.0195)$ & $(0.0212)$ \\
Urban & 0.0165 & 0.00131 & 0.00427 \\
& $(0.0192)$ & $(0.0217)$ & $(0.0173)$ \\
Rich & 0.00588 & $0.0378 * *$ & 0.00831 \\
& $(0.0126)$ & $(0.0127)$ & $(0.0141)$ \\
Unemployed & $0.0315 * * *$ & $0.0417 *$ & 0.0238 \\
Female x Stringent & $(0.00585)$ & $(0.0189)$ & $(0.0184)$ \\
Young x Stringent & -0.0507 & $-0.0537 *$ & $-0.0909 * *$ \\
& $(0.0348)$ & $(0.0263)$ & $(0.0331)$ \\
College x Stringent & 0.0176 & 0.0420 & 0.00545 \\
& $(0.0228)$ & $(0.0255)$ & $(0.0243)$ \\
Urban x Stringent & -0.00203 & -0.0359 & 0.0189 \\
& $(0.0336)$ & $(0.0417)$ & $(0.0330)$ \\
Rich x Stringent & -0.00986 & 0.0382 & 0.0254 \\
& $(0.0209)$ & $(0.0223)$ & $(0.0229)$ \\
Unemployed x Stringent & 0.00359 & 0.00805 & 0.0395 \\
& $(0.0233)$ & $(0.0145)$ & $(0.0355)$ \\
Observations & $-0.0633 * *$ & $-0.0840 * *$ & -0.0524 \\
Country FE & $(0.0272)$ & $(0.0333)$ & $(0.0360)$ \\
& 0.00954 & 0.00184 & 0.0577 \\
& $(0.0380)$ & $(0.0396)$ & $(0.0357)$ \\
& & & \\
& 11,197 & 11,197 & 11,197 \\
& Yes & Yes & Yes \\
\hline
\end{tabular}

Note: Results from Equation (2) where the dependent variable is an indicator that equals 1 for favorable assessment of the government performance and interaction term Stringent is a dummy that equals 1 for above the median stringency index in OxCGRT. Errors are clustered at the country-level and regressions are weighted by public weights provided in the survey. ${ }^{* * *} p<0.01,{ }^{* *} p<0.05$ and ${ }^{*} p<0.1$ 
Table 6: Assessment of Government Performance by Timing of COVID-19 Spread

\begin{tabular}{|c|c|c|c|}
\hline & $\begin{array}{c}\text { (1) } \\
\text { Overall }\end{array}$ & $\begin{array}{c}\text { (2) } \\
\text { Health }\end{array}$ & $\begin{array}{c}(3) \\
\text { Economic }\end{array}$ \\
\hline Female & $\begin{array}{l}-0.0239 \\
(0.0135)\end{array}$ & $\begin{array}{c}-0.0461^{* *} \\
(0.0167)\end{array}$ & $\begin{array}{c}-0.0546^{* * *} \\
(0.0130)\end{array}$ \\
\hline Young & $\begin{array}{l}0.00227 \\
(0.0169)\end{array}$ & $\begin{array}{l}-0.00463 \\
(0.0241)\end{array}$ & $\begin{array}{l}-0.0237 \\
(0.0182)\end{array}$ \\
\hline College & $\begin{array}{l}0.00959 \\
(0.0120)\end{array}$ & $\begin{array}{c}0.0116 \\
(0.0146)\end{array}$ & $\begin{array}{c}0.0118 \\
(0.0130)\end{array}$ \\
\hline Urban & $\begin{array}{l}0.00365 \\
(0.0112)\end{array}$ & $\begin{array}{l}0.0364^{* * *} \\
(0.00901)\end{array}$ & $\begin{array}{c}0.0150 \\
(0.0148)\end{array}$ \\
\hline Rich & $\begin{array}{l}0.00462 \\
(0.0169)\end{array}$ & $\begin{array}{l}0.00931 \\
(0.0236)\end{array}$ & $\begin{array}{l}0.00669 \\
(0.0203)\end{array}$ \\
\hline Unemployed & $\begin{array}{l}-0.0427^{*} \\
(0.0223)\end{array}$ & $\begin{array}{c}-0.0542^{* * *} \\
(0.0212)\end{array}$ & $\begin{array}{c}-0.0621^{* *} \\
(0.0229)\end{array}$ \\
\hline Female $\mathrm{x}$ Down & $\begin{array}{l}0.0255^{*} \\
(0.0135)\end{array}$ & $\begin{array}{c}0.0118 \\
(0.0167)\end{array}$ & $\begin{array}{c}0.0441^{* * *} \\
(0.0130)\end{array}$ \\
\hline Young x Down & $\begin{array}{c}-0.0529 * * \\
(0.0169)\end{array}$ & $\begin{array}{c}-0.0106 \\
(0.0241)\end{array}$ & $\begin{array}{l}-0.0145 \\
(0.0182)\end{array}$ \\
\hline College x Down & $\begin{array}{c}0.0399 * * * \\
(0.0120)\end{array}$ & $\begin{array}{c}0.0612^{* * *} \\
(0.0146)\end{array}$ & $\begin{array}{l}0.0243^{*} \\
(0.0130)\end{array}$ \\
\hline Urban x Down & $\begin{array}{c}0.0383^{* * *} \\
(0.0112)\end{array}$ & $\begin{array}{l}0.0628 * * * \\
(0.00901)\end{array}$ & $\begin{array}{c}0.0613 * * * \\
(0.0148)\end{array}$ \\
\hline Rich x Down & $\begin{array}{c}0.0183 \\
(0.0169)\end{array}$ & $\begin{array}{c}-0.00701 \\
(0.0236)\end{array}$ & $\begin{array}{l}-0.0352 \\
(0.0203)\end{array}$ \\
\hline Unemployed $\mathrm{x}$ Down & $\begin{array}{c}-0.0607^{* * *} \\
(0.0223)\end{array}$ & $\begin{array}{c}0.0286 \\
(0.0212)\end{array}$ & $\begin{array}{c}-0.101 * * * \\
(0.0229)\end{array}$ \\
\hline $\begin{array}{l}\text { Observations } \\
\text { Country FE }\end{array}$ & $\begin{array}{c}11,197 \\
\text { Yes }\end{array}$ & $\begin{array}{c}11,197 \\
\text { Yes }\end{array}$ & $\begin{array}{c}11,197 \\
\text { Yes }\end{array}$ \\
\hline
\end{tabular}

Note: Results from Equation (2) where the dependent variable is an indicator that equals 1 for favorable assessment of the government performance and interaction term Down is a dummy that equals 1 for countries that saw an initial surge followed by a downward trend in COVID-19 cases at the time of survey. Errors are clustered at the countrylevel and regressions are weighted by public weights provided in the survey. ${ }^{* *} \mathrm{p}<0.01,{ }^{* *} \mathrm{p}<0.05$ and ${ }^{*} \mathrm{p}<0.1$ 
Table 7: Assessment of Government Performance by Initial Level of Inequality

\begin{tabular}{|c|c|c|c|}
\hline & $\begin{array}{c}\text { (1) } \\
\text { Overall }\end{array}$ & $\begin{array}{c}(2) \\
\text { Health }\end{array}$ & $\begin{array}{c}\text { (3) } \\
\text { Economic }\end{array}$ \\
\hline Female & $\begin{array}{l}-0.00959 \\
(0.00935)\end{array}$ & $\begin{array}{c}-0.0362 * * * \\
(0.00639)\end{array}$ & $\begin{array}{c}-0.0419 * * \\
(0.0140)\end{array}$ \\
\hline Young & $\begin{array}{l}0.00203 \\
(0.0203)\end{array}$ & $\begin{array}{c}0.0203 \\
(0.0229)\end{array}$ & $\begin{array}{l}-0.0233 \\
(0.0203)\end{array}$ \\
\hline College & $\begin{array}{c}0.0224 \\
(0.0142)\end{array}$ & $\begin{array}{c}0.0224 \\
(0.0175)\end{array}$ & $\begin{array}{c}0.0255 \\
(0.0143)\end{array}$ \\
\hline Urban & $\begin{array}{c}0.00216 \\
(0.00973)\end{array}$ & $\begin{array}{c}0.0358 * * * * \\
(0.0100)\end{array}$ & $\begin{array}{c}0.0161 \\
(0.0180)\end{array}$ \\
\hline Rich & $\begin{array}{l}0.0286 * * * \\
(0.00879)\end{array}$ & $\begin{array}{c}0.0253 \\
(0.0210)\end{array}$ & $\begin{array}{c}0.0139 \\
(0.0218)\end{array}$ \\
\hline Unemployed & $\begin{array}{l}-0.0226 \\
(0.0202)\end{array}$ & $\begin{array}{c}-0.0443 * * \\
(0.0166)\end{array}$ & $\begin{array}{c}-0.0656 * * \\
(0.0241)\end{array}$ \\
\hline Female $x$ Gini & $\begin{array}{l}-0.0401 \\
(0.0324)\end{array}$ & $\begin{array}{l}-0.0306 \\
(0.0479)\end{array}$ & $\begin{array}{l}-0.0272 \\
(0.0273)\end{array}$ \\
\hline Young x Gini & $\begin{array}{l}-0.0173 \\
(0.0303)\end{array}$ & $\begin{array}{c}-0.0762 * * \\
(0.0324)\end{array}$ & $\begin{array}{l}-0.00890 \\
(0.0330)\end{array}$ \\
\hline College x Gini & $\begin{array}{l}-0.0272 \\
(0.0206)\end{array}$ & $\begin{array}{l}-0.0172 \\
(0.0312)\end{array}$ & $\begin{array}{l}-0.0351 \\
(0.0199)\end{array}$ \\
\hline Urban x Gini & $\begin{array}{c}0.0120 \\
(0.0318)\end{array}$ & $\begin{array}{c}0.0133 \\
(0.0200)\end{array}$ & $\begin{array}{l}0.00665 \\
(0.0182)\end{array}$ \\
\hline Rich x Gini & $\begin{array}{l}-0.0682^{*} \\
(0.0341)\end{array}$ & $\begin{array}{l}-0.0519 \\
(0.0479)\end{array}$ & $\begin{array}{l}-0.0312 \\
(0.0409)\end{array}$ \\
\hline Unemployed x Gini & $\begin{array}{c}-0.0682 * \\
(0.0312)\end{array}$ & $\begin{array}{l}-0.0255 \\
(0.0443)\end{array}$ & $\begin{array}{c}-0.0103 \\
(0.0507)\end{array}$ \\
\hline $\begin{array}{l}\text { Observations } \\
\text { Country FE }\end{array}$ & $\begin{array}{c}11,197 \\
\text { Yes }\end{array}$ & $\begin{array}{c}11,197 \\
\text { Yes }\end{array}$ & $\begin{array}{c}11,197 \\
\text { Yes }\end{array}$ \\
\hline
\end{tabular}

Note: Results from Equation (2) where the dependent variable is an indicator that equals 1 for favorable assessment of the government performance and interaction term Gini is a dummy that equals 1 for above median inequality by Gini Index. Errors are clustered at the country-level and regressions are weighted by public weights provided in the survey. ${ }^{* *} p<0.01,{ }^{* *} p<0.05$ and ${ }^{*} p<0.1$ 


\begin{tabular}{|c|c|c|c|c|c|c|c|c|}
\hline \multicolumn{9}{|c|}{ Table 8: Beliefs about Social and Economic Concerns- Baseline } \\
\hline & (1) & $(2)$ & (3) & (4) & (5) & (6) & (7) & $(8)$ \\
\hline & $\begin{array}{l}\text { Vulnerable } \\
\text { more affected }\end{array}$ & $\begin{array}{c}\text { Vulnerable more } \\
\text { affected }\end{array}$ & $\begin{array}{c}\text { Capitalism is } \\
\text { harmful }\end{array}$ & $\begin{array}{c}\text { Capitalism is } \\
\text { harmful }\end{array}$ & $\begin{array}{c}\text { Prolonged job } \\
\text { losses }\end{array}$ & $\begin{array}{c}\text { Prolonged job } \\
\text { losses }\end{array}$ & $\begin{array}{c}\text { Threat of } \\
\text { automation }\end{array}$ & $\begin{array}{c}\text { Threat of } \\
\text { automation }\end{array}$ \\
\hline \multirow[t]{2}{*}{ Female } & $0.0411^{* *}$ & 0.0278 & 0.0108 & -0.00377 & 0.0178 & 0.0162 & 0.0107 & 0.0114 \\
\hline & $(0.0171)$ & $(0.0155)$ & $(0.0125)$ & $(0.0162)$ & $(0.0155)$ & $(0.0224)$ & $(0.0141)$ & $(0.0169)$ \\
\hline \multirow[t]{2}{*}{ Young } & $-0.0514^{* * *}$ & $-0.0317^{*}$ & $-0.0337^{*}$ & $-0.0312^{*}$ & -0.00986 & 0.00122 & $-0.0493^{* *}$ & -0.0360 \\
\hline & $(0.0157)$ & $(0.0147)$ & $(0.0158)$ & $(0.0161)$ & $(0.0213)$ & $(0.0253)$ & $(0.0194)$ & $(0.0202)$ \\
\hline \multirow[t]{2}{*}{ College } & -0.00159 & -0.00506 & -0.0239 & -0.0135 & -0.0118 & -0.00211 & -0.0159 & 0.00551 \\
\hline & $(0.0126)$ & $(0.0142)$ & $(0.0166)$ & $(0.0203)$ & $(0.0169)$ & $(0.0189)$ & $(0.0160)$ & $(0.0185)$ \\
\hline \multirow[t]{2}{*}{ Urban } & $0.0458^{* *}$ & $0.0596^{* *}$ & 0.0273 & 0.0370 & $0.0455^{\circ}$ & $0.0620^{\circ}$ & $0.0593^{* * *}$ & $0.0686^{* 8 *}$ \\
\hline & $(0.0193)$ & $(0.0259)$ & $(0.0233)$ & $(0.0278)$ & $(0.0211)$ & $(0.0287)$ & $(0.0184)$ & $(0.0195)$ \\
\hline \multirow[t]{2}{*}{ Rich } & 0.0178 & 0.0170 & -0.00970 & -0.00571 & 0.0103 & -0.0112 & 0.0175 & 0.00586 \\
\hline & $(0.0214)$ & $(0.0206)$ & $(0.0247)$ & $(0.0311)$ & $(0.0183)$ & $(0.0231)$ & $(0.0273)$ & $(0.0284)$ \\
\hline \multirow[t]{2}{*}{ Unemployed } & $0.0656^{* *}$ & $0.0693^{* * *}$ & $0.0866^{* * *}$ & 0.0563 & $0.104^{* * *}$ & $0.140^{* * * *}$ & -0.00637 & -0.0109 \\
\hline & $(0.0210)$ & $(0.0198)$ & $(0.0162)$ & $(0.0320)$ & $(0.0254)$ & $(0.0236)$ & $(0.0215)$ & $(0.0253)$ \\
\hline \multirow[t]{2}{*}{ Small firm } & & -0.0124 & & $-0.0395^{* *}$ & & $-0.0328^{*}$ & & $-0.0541^{*: * *}$ \\
\hline & & $(0.0140)$ & & $(0.0177)$ & & $(0.0177)$ & & $(0.0161)$ \\
\hline \multirow[t]{2}{*}{ Tele-work } & & -0.00424 & & -0.0226 & & $-0.0372^{*}$ & & -0.0257 \\
\hline & & $(0.0138)$ & & $(0.0134)$ & & $(0.0191)$ & & $(0.0184)$ \\
\hline Observations & 12,398 & 7,047 & 12,398 & 7,047 & 12,398 & 7,047 & 12,398 & 7,047 \\
\hline Country FE & Yes & Yes & Yes & Yes & Yes & Yes & Yes & Yes \\
\hline
\end{tabular}

Table 9: Beliefs about Social and Economic Concerns-Effect of Being Personally Affected

\begin{tabular}{|c|c|c|c|c|c|c|c|c|}
\hline & (1) & (2) & (3) & (4) & (5) & (6) & (7) & (8) \\
\hline & $\begin{array}{c}\text { Vulnerable more } \\
\text { affected }\end{array}$ & $\begin{array}{c}\text { Vulnerable more } \\
\text { affected }\end{array}$ & $\begin{array}{l}\text { Capitalism is } \\
\text { harmful }\end{array}$ & $\begin{array}{l}\text { Capitalism is } \\
\text { harmful }\end{array}$ & $\begin{array}{c}\text { Prolonged job } \\
\text { losses }\end{array}$ & $\begin{array}{c}\text { Prolonged job } \\
\text { losses }\end{array}$ & $\begin{array}{c}\text { Threat of } \\
\text { automation }\end{array}$ & $\begin{array}{c}\text { Threat of } \\
\text { automation }\end{array}$ \\
\hline \multirow[t]{2}{*}{ Lost Job } & $0.0593^{* *}$ & & $0.0512^{*}$ & & $0.145^{* * *}$ & & -0.0194 & \\
\hline & $(0.0216)$ & & $(0.0281)$ & & $(0.0190)$ & & $(0.0224)$ & \\
\hline \multirow[t]{2}{*}{ Infected } & & $0.130 * * *$ & & $0.129^{* * *}$ & & $0.156^{* * *}$ & & $0.149^{* * *}$ \\
\hline & & $(0.0362)$ & & $(0.0394)$ & & $(0.0414)$ & & $(0.0376)$ \\
\hline Observations & 12,416 & 12,416 & 12,416 & 12,416 & 12,416 & 12,416 & 12,416 & 12,416 \\
\hline Country FE & Yes & Yes & Yes & Yes & Yes & Yes & Yes & Yes \\
\hline
\end{tabular}

Note: Results from Equation (1) where the dependent variable is an indicator that equals 1 for strong concerns about social problems. Individual controls include gender, age, urban, education, employment status and household income dummies. Errors are clustered at the country-level and regressions are weighted by public weights provided in the survey. ${ }^{* *} p<0.01,{ }^{* *} p<0.05$ and ${ }^{*} p<0.1$ 


\begin{tabular}{|c|c|c|c|c|}
\hline \multicolumn{5}{|c|}{$\begin{array}{c}\text { Table 10: Beliefs about Social and Economic Concerns- Advanced vs } \\
\text { Emerging Market Economies }\end{array}$} \\
\hline & $\begin{array}{c}\text { (1) } \\
\begin{array}{c}\text { Vulnerable more } \\
\text { affected }\end{array}\end{array}$ & $\begin{array}{l}(2) \\
\text { Capitalism is harmful }\end{array}$ & $\begin{array}{c}(3) \\
\text { Prolonged job losses }\end{array}$ & $\begin{array}{c}\text { (4) } \\
\text { Threat of automation }\end{array}$ \\
\hline Female & 0.0188 & $0.0299 * *$ & -0.00260 & $\begin{array}{l}-0.00499 \\
(0.0141)\end{array}$ \\
\hline Young & $\begin{array}{l}-0.0440 \\
(0.0276)\end{array}$ & $\begin{array}{c}-0.0267^{*} \\
(0.0142)\end{array}$ & $\begin{array}{c}0.0293 \\
(0.0237)\end{array}$ & $\begin{array}{l}-0.0236 \\
(0.0238)\end{array}$ \\
\hline College & $\begin{array}{r}-0.00703 \\
(0.0121)\end{array}$ & $\begin{array}{l}-0.0206 \\
(0.0149)\end{array}$ & $\begin{array}{l}-0.0115 \\
(0.0156)\end{array}$ & $\begin{array}{l}-0.00748 \\
(0.0137)\end{array}$ \\
\hline Urban & $\begin{array}{l}0.0463^{*} \\
(0.0236)\end{array}$ & $\begin{array}{c}0.0312 \\
(0.0281)\end{array}$ & $\begin{array}{l}0.0454^{*} \\
(0.0245)\end{array}$ & $\begin{array}{l}0.0572 * * \\
(0.0204)\end{array}$ \\
\hline Rich & $\begin{array}{l}-0.0171 \\
(0.0125)\end{array}$ & $\begin{array}{c}-0.0473 * * * \\
(0.0127)\end{array}$ & $\begin{array}{l}-0.0169^{*} \\
(0.00914)\end{array}$ & $\begin{array}{c}-0.0341^{* * *} \\
(0.0108)\end{array}$ \\
\hline Unemployed & $\begin{array}{c}0.0798 * * * * \\
(0.0170)\end{array}$ & $\begin{array}{c}0.0841^{* * * *} \\
(0.0193)\end{array}$ & $\begin{array}{l}0.109 * * * \\
(0.0310)\end{array}$ & $\begin{array}{l}0.00826 \\
(0.0191)\end{array}$ \\
\hline Female $x$ EM & $\begin{array}{c}0.0526 \\
(0.0392)\end{array}$ & $\begin{array}{c}-0.0589 * * \\
(0.0218)\end{array}$ & $\begin{array}{c}0.0486 \\
(0.0323)\end{array}$ & $\begin{array}{c}0.0330 \\
(0.0311)\end{array}$ \\
\hline Young $\mathrm{x}$ EM & $\begin{array}{l}-0.0135 \\
(0.0300)\end{array}$ & $\begin{array}{l}-0.0123 \\
(0.0350)\end{array}$ & $\begin{array}{c}-0.0838^{* *} \\
(0.0332)\end{array}$ & $\begin{array}{l}-0.0535 \\
(0.0340)\end{array}$ \\
\hline College $x$ EM & $\begin{array}{c}0.0165 \\
(0.0304)\end{array}$ & $\begin{array}{l}8.24 \mathrm{e}-05 \\
(0.0394)\end{array}$ & $\begin{array}{l}-0.00174 \\
(0.0381)\end{array}$ & $\begin{array}{l}-0.0208 \\
(0.0354)\end{array}$ \\
\hline Urban x EM & $\begin{array}{l}-0.0175 \\
(0.0267)\end{array}$ & $\begin{array}{l}-0.0289 \\
(0.0370)\end{array}$ & $\begin{array}{l}-0.0191 \\
(0.0374)\end{array}$ & $\begin{array}{c}-0.0114 \\
(0.0402)\end{array}$ \\
\hline Rich x EM & $\begin{array}{l}0.0865^{* *} \\
(0.0380)\end{array}$ & $\begin{array}{c}0.102 * \\
(0.0460)\end{array}$ & $\begin{array}{l}0.0666^{*} \\
(0.0346)\end{array}$ & $\begin{array}{l}0.129 * * \\
(0.0415)\end{array}$ \\
\hline Unemp x EM & $\begin{array}{c}-0.0572 \\
(0.0508)\end{array}$ & $\begin{array}{l}0.00237 \\
(0.0353)\end{array}$ & $\begin{array}{l}-0.0265 \\
(0.0520)\end{array}$ & $\begin{array}{l}-0.0624 \\
(0.0516)\end{array}$ \\
\hline Observations & 12,398 & 12,398 & 12,398 & 12,398 \\
\hline Country FE & Yes & Yes & Yes & Yes \\
\hline $\begin{array}{l}\text { Note: Results from Equ } \\
\text { social problems and int } \\
\text { are clustered at the col } \\
{ }^{* *} p<0.05 \text { and }{ }^{*} p<0.1\end{array}$ & $\begin{array}{l}\text { (2) where the de } \\
\text { on term EM is a } \\
\text { evel and regress }\end{array}$ & $\begin{array}{l}\text { dent variable is an ir } \\
\text { my that equals } 1 \mathrm{fo} \\
\text { are weighted by pu }\end{array}$ & $\begin{array}{l}\text { dicator that equals } \\
\text { emerging econom } \\
\text { lic weights provide }\end{array}$ & $\begin{array}{l}\text { for strong concern } \\
s \text { and } 0 \text { otherwise. } \\
\text { in the survey. }{ }^{* *} p\end{array}$ \\
\hline
\end{tabular}




\begin{tabular}{|c|c|c|c|c|}
\hline \multicolumn{5}{|c|}{$\begin{array}{l}\text { Table 11: Beliefs about Social and Economic Concerns by Stringency of } \\
\text { Containment Measures }\end{array}$} \\
\hline & $\begin{array}{c}\text { (1) } \\
\begin{array}{c}\text { Vulnerable more } \\
\text { affected }\end{array} \\
\end{array}$ & $\begin{array}{l}\text { (2) } \\
\text { Capitalism is } \\
\text { harmful }\end{array}$ & $\begin{array}{c}\text { (3) } \\
\text { Prolonged job } \\
\text { losses } \\
\end{array}$ & $\begin{array}{c}\text { (4) } \\
\text { Threat of } \\
\text { automation }\end{array}$ \\
\hline Female & $\begin{array}{c}0.0250 \\
(0.0142)\end{array}$ & $\begin{array}{c}0.0227 \\
(0.0151)\end{array}$ & $\begin{array}{l}-0.00351 \\
(0.0130)\end{array}$ & $\begin{array}{r}-0.00676 \\
(0.0124)\end{array}$ \\
\hline Young & $\begin{array}{l}-0.0394 \\
(0.0272)\end{array}$ & $\begin{array}{l}-0.0378 \\
(0.0226)\end{array}$ & $\begin{array}{l}0.00959 \\
(0.0354)\end{array}$ & $\begin{array}{l}-0.0372 \\
(0.0306)\end{array}$ \\
\hline College & $\begin{array}{l}-0.0159 \\
(0.0127)\end{array}$ & $\begin{array}{l}-0.0279 \\
(0.0191)\end{array}$ & $\begin{array}{l}-0.0222 \\
(0.0215)\end{array}$ & $\begin{array}{l}-0.0213 \\
(0.0221)\end{array}$ \\
\hline Urban & $\begin{array}{l}0.0603 * * \\
(0.0229)\end{array}$ & $\begin{array}{c}0.0448 \\
(0.0260)\end{array}$ & $\begin{array}{l}0.0588^{*} \\
(0.0268)\end{array}$ & $\begin{array}{l}0.0711^{* * * *} \\
(0.0190)\end{array}$ \\
\hline Rich & $\begin{array}{l}0.00985 \\
(0.0308)\end{array}$ & $\begin{array}{l}-0.00891 \\
(0.0333)\end{array}$ & $\begin{array}{l}0.0143 \\
(0.0268)\end{array}$ & $\begin{array}{c}0.0118 \\
(0.0338)\end{array}$ \\
\hline Unemployed & $\begin{array}{l}0.0901 * * * \\
(0.0171)\end{array}$ & $\begin{array}{c}0.0827 * * * \\
(0.0204)\end{array}$ & $\begin{array}{l}0.114^{* *} \\
(0.0361)\end{array}$ & $\begin{array}{c}0.0120 \\
(0.0229)\end{array}$ \\
\hline Female $\mathrm{x}$ Stringent & $\begin{array}{c}0.0433 \\
(0.0387)\end{array}$ & $\begin{array}{l}-0.0316 \\
(0.0245)\end{array}$ & $\begin{array}{l}0.0584^{*} \\
(0.0286)\end{array}$ & $\begin{array}{c}0.0481 \\
(0.0295)\end{array}$ \\
\hline Young $\mathrm{x}$ Stringent & $\begin{array}{l}-0.0260 \\
(0.0280)\end{array}$ & $\begin{array}{l}0.00885 \\
(0.0322)\end{array}$ & $\begin{array}{l}-0.0442 \\
(0.0366)\end{array}$ & $\begin{array}{l}-0.0278 \\
(0.0352)\end{array}$ \\
\hline College $\mathrm{x}$ Stringent & $\begin{array}{c}0.0390 \\
(0.0251)\end{array}$ & $\begin{array}{c}0.0131 \\
(0.0388)\end{array}$ & $\begin{array}{c}0.0256 \\
(0.0312)\end{array}$ & $\begin{array}{c}0.0127 \\
(0.0283)\end{array}$ \\
\hline Urban $x$ Stringent & $\begin{array}{l}-0.0570 * \\
(0.0257)\end{array}$ & $\begin{array}{l}-0.0628 \\
(0.0396)\end{array}$ & $\begin{array}{l}-0.0530 \\
(0.0310)\end{array}$ & $\begin{array}{l}-0.0471 \\
(0.0395)\end{array}$ \\
\hline Rich x Stringent & $\begin{array}{c}0.0242 \\
(0.0383)\end{array}$ & $\begin{array}{c}0.000922 \\
(0.0470)\end{array}$ & $\begin{array}{l}-0.00991 \\
(0.0323)\end{array}$ & $\begin{array}{c}0.0170 \\
(0.0563)\end{array}$ \\
\hline Unemp $x$ Stringent & $\begin{array}{l}-0.0667 \\
(0.0402)\end{array}$ & $\begin{array}{c}0.0109 \\
(0.0330)\end{array}$ & $\begin{array}{l}-0.0283 \\
(0.0480)\end{array}$ & $\begin{array}{l}-0.0509 \\
(0.0494)\end{array}$ \\
\hline $\begin{array}{l}\text { Observations } \\
\text { Country FE }\end{array}$ & $\begin{array}{c}12,398 \\
\text { Yes }\end{array}$ & $\begin{array}{c}12,398 \\
\text { Yes }\end{array}$ & $\begin{array}{c}12,398 \\
\text { Yes }\end{array}$ & $\begin{array}{c}12,398 \\
\text { Yes }\end{array}$ \\
\hline $\begin{array}{l}\text { Note: Results from Equation (2 } \\
\text { social problems and interaction } \\
\text { OxCGRT. Errors are clustered a } \\
\text { survey. }{ }^{* * *} \mathrm{p}<0.01,{ }^{* *} \mathrm{p}<0.05 \text { an }\end{array}$ & the country-level a & d regressions & $\begin{array}{l}\text { dicator that equ } \\
1 \text { for above th } \\
\text { veighted by pu }\end{array}$ & $\begin{array}{l}\text { for strong cc } \\
\text { dian stringen } \\
\text { eights provi }\end{array}$ \\
\hline
\end{tabular}


Table 12: Beliefs about Social and Economic Concerns by Timing of COVID-19 Spread

\begin{tabular}{|c|c|c|c|c|}
\hline & $\begin{array}{l}\text { (1) } \\
\text { Vulnerable more affected }\end{array}$ & $\begin{array}{c}\text { (2) } \\
\text { Capitalism is harmful }\end{array}$ & $\begin{array}{c}\text { (3) } \\
\text { Prolonged job losses }\end{array}$ & $\begin{array}{c}\text { (4) } \\
\text { Threat of automation }\end{array}$ \\
\hline Female & $\begin{array}{c}0.0453^{* *} \\
(0.0191)\end{array}$ & $\begin{array}{c}0.0161 \\
(0.0139)\end{array}$ & $\begin{array}{c}0.0286 \\
(0.0163)\end{array}$ & $\begin{array}{c}0.0152 \\
(0.0164)\end{array}$ \\
\hline Young & $\begin{array}{c}-0.0619 * * * \\
(0.0165)\end{array}$ & $\begin{array}{l}-0.0217 \\
(0.0126)\end{array}$ & $\begin{array}{c}0.0115 \\
(0.0189)\end{array}$ & $\begin{array}{l}-0.0328 \\
(0.0188)\end{array}$ \\
\hline College & $\begin{array}{c}0.00978 \\
(0.0124)\end{array}$ & $\begin{array}{l}-0.0132 \\
(0.0167)\end{array}$ & $\begin{array}{l}0.00485 \\
(0.0141)\end{array}$ & $\begin{array}{l}0.00193 \\
(0.0111)\end{array}$ \\
\hline Urban & $\begin{array}{l}0.0475^{* *} \\
(0.0212)\end{array}$ & $\begin{array}{c}0.0309 \\
(0.0259)\end{array}$ & $\begin{array}{l}0.0470^{8} \\
(0.0220)\end{array}$ & $\begin{array}{l}0.0579 * * \\
(0.0206)\end{array}$ \\
\hline Rich & $\begin{array}{l}-0.000600 \\
(0.0167)\end{array}$ & $\begin{array}{l}-0.0360^{*} \\
(0.0170)\end{array}$ & $\begin{array}{l}-0.00392 \\
(0.0104)\end{array}$ & $\begin{array}{l}-0.00265 \\
(0.0238)\end{array}$ \\
\hline Unemployed & $\begin{array}{l}0.0612^{* *} \\
(0.0230)\end{array}$ & $\begin{array}{c}0.0760 * 8 * \\
(0.0155)\end{array}$ & $\begin{array}{c}0.0900 * * * \\
(0.0256)\end{array}$ & $\begin{array}{l}-0.0184 \\
(0.0213)\end{array}$ \\
\hline Female $\mathrm{x}$ Down & $\begin{array}{l}-0.0270 \\
(0.0363)\end{array}$ & $\begin{array}{l}-0.0299 \\
(0.0261)\end{array}$ & $\begin{array}{c}-0.0523^{* *} \\
(0.0209)\end{array}$ & $\begin{array}{l}-0.0219 \\
(0.0203)\end{array}$ \\
\hline Young x Down & $\begin{array}{l}0.0671 * * \\
(0.0231)\end{array}$ & $\begin{array}{l}-0.0685 \\
(0.0384)\end{array}$ & $\begin{array}{l}-0.119 * * * \\
(0.0240)\end{array}$ & $\begin{array}{l}-0.0913^{* * *} \\
(0.0227)\end{array}$ \\
\hline College x Down & $\begin{array}{c}-0.0573 * * * \\
(0.0124)\end{array}$ & $\begin{array}{l}-0.0412 \\
(0.0247)\end{array}$ & $\begin{array}{c}-0.0709 * * \\
(0.0234)\end{array}$ & $\begin{array}{c}-0.0803 * * * \\
(0.0224)\end{array}$ \\
\hline Urban x Down & $\begin{array}{c}-0.0160 \\
(0.0353)\end{array}$ & $\begin{array}{l}-0.0456 \\
(0.0259)\end{array}$ & $\begin{array}{l}-0.0181 \\
(0.0713)\end{array}$ & $\begin{array}{l}0.00470 \\
(0.0206)\end{array}$ \\
\hline Rich x Down & $\begin{array}{c}0.0935 \\
(0.0556)\end{array}$ & $\begin{array}{l}0.136^{* \%} \\
(0.0551)\end{array}$ & $\begin{array}{c}0.0741 \\
(0.0575)\end{array}$ & $\begin{array}{c}0.0996 \\
(0.0727)\end{array}$ \\
\hline Unemp $\mathrm{x}$ Down & $\begin{array}{c}0.0333 \\
(0.0234)\end{array}$ & $\begin{array}{l}0.0981^{* * *} \\
(0.0164)\end{array}$ & $\begin{array}{l}0.155^{* * *} \\
(0.0318)\end{array}$ & $\begin{array}{l}0.128^{* * *} \\
(0.0272)\end{array}$ \\
\hline $\begin{array}{l}\text { Observations } \\
\text { Country FE }\end{array}$ & $\begin{array}{c}12,398 \\
\text { Yes }\end{array}$ & $\begin{array}{c}12,398 \\
\text { Yes }\end{array}$ & $\begin{array}{c}12,398 \\
\text { Yes }\end{array}$ & $\begin{array}{c}12,398 \\
\text { Yes }\end{array}$ \\
\hline
\end{tabular}

Note: Results from Equation (2) where the dependent variable is an indicator that equals 1 for strong concerns about social problems and interaction term Down is a dummy that equals 1 for countries that saw an initial surge followed by a downward trend in COVID-19 cases at the time of survey. Errors are clustered at the country-level and regressions are weighted by public weights provided in the survey. ${ }^{* *} p<0.01,{ }^{* *} p<0.05$ and ${ }^{*} p<0.1$ 
Table 13: Beliefs about Social and Economic Concerns by Initial Level of Inequality

\begin{tabular}{|c|c|c|c|c|}
\hline & $\begin{array}{c}\text { (1) } \\
\text { Vulnerable } \\
\text { more affected }\end{array}$ & $\begin{array}{l}\text { (2) } \\
\text { Capitalism is } \\
\text { harmful }\end{array}$ & $\begin{array}{c}\text { (3) } \\
\text { Prolonged job } \\
\text { losses }\end{array}$ & $\begin{array}{c}\text { (4) } \\
\text { Threat of } \\
\text { automation }\end{array}$ \\
\hline Female & $\begin{array}{c}0.0145 \\
(0.0133)\end{array}$ & $\begin{array}{c}0.0257 \\
(0.0160)\end{array}$ & $\begin{array}{l}0.00291 \\
(0.0126)\end{array}$ & $\begin{array}{l}0.00106 \\
(0.0117)\end{array}$ \\
\hline Young & $\begin{array}{l}-0.0515^{*} \\
(0.0261)\end{array}$ & $\begin{array}{l}-0.0201 \\
(0.0167)\end{array}$ & $\begin{array}{c}0.0175 \\
(0.0236)\end{array}$ & $\begin{array}{l}-0.0336 \\
(0.0220)\end{array}$ \\
\hline College & $\begin{array}{l}-0.0113 \\
(0.0117)\end{array}$ & $\begin{array}{c}-0.0173 \\
(0.0156)\end{array}$ & $\begin{array}{l}-0.00670 \\
(0.0175)\end{array}$ & $\begin{array}{c}-0.0110 \\
(0.0147)\end{array}$ \\
\hline Urban & $\begin{array}{l}0.0281^{*} \\
(0.0142)\end{array}$ & $\begin{array}{c}0.0109 \\
(0.0152)\end{array}$ & $\begin{array}{c}0.0269 \\
(0.0156)\end{array}$ & $\begin{array}{c}0.0506^{*} \cdot k \\
(0.0164)\end{array}$ \\
\hline Rich & $\begin{array}{l}-0.00428 \\
(0.0216)\end{array}$ & $\begin{array}{l}-0.0295 \\
(0.0226)\end{array}$ & $\begin{array}{l}-0.0136 \\
(0.0110)\end{array}$ & $\begin{array}{l}-0.00804 \\
(0.0290)\end{array}$ \\
\hline Unemployed & $\begin{array}{c}0.0900^{*} \text { 水水 } \\
(0.0175)\end{array}$ & $\begin{array}{c}0.0982^{*} k_{k} * \\
(0.0188)\end{array}$ & 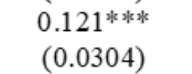 & $\begin{array}{c}0.0148 \\
(0.0209)\end{array}$ \\
\hline Female x Gini & $\begin{array}{c}0.0701^{*} * k^{k} \\
(0.0298)\end{array}$ & $\begin{array}{l}-0.0417^{*} \\
(0.0190)\end{array}$ & $\begin{array}{c}0.0382 \\
(0.0338)\end{array}$ & $\begin{array}{c}0.0249 \\
(0.0314)\end{array}$ \\
\hline Young x Gini & $\begin{array}{l}0.00102 \\
(0.0291)\end{array}$ & $\begin{array}{l}-0.0329 \\
(0.0297)\end{array}$ & $\begin{array}{l}-0.0649 \\
(0.0379)\end{array}$ & $\begin{array}{l}-0.0371 \\
(0.0371)\end{array}$ \\
\hline College x Gini & $\begin{array}{c}0.0204 \\
(0.0295)\end{array}$ & $\begin{array}{c}-0.0182 \\
(0.0384)\end{array}$ & $\begin{array}{c}-0.0177 \\
(0.0372)\end{array}$ & $\begin{array}{c}-0.0157 \\
(0.0362)\end{array}$ \\
\hline Urban x Gini & $\begin{array}{c}0.0699 \\
(0.0435)\end{array}$ & $\begin{array}{c}0.0652 \\
(0.0628)\end{array}$ & $\begin{array}{c}0.0725 \\
(0.0497)\end{array}$ & $\begin{array}{c}0.0336 \\
(0.0497)\end{array}$ \\
\hline Rich x Gini & $\begin{array}{c}0.0546 \\
(0.0413)\end{array}$ & $\begin{array}{c}0.0499 \\
(0.0532)\end{array}$ & $\begin{array}{c}0.0593 \\
(0.0354)\end{array}$ & $\begin{array}{c}0.0638 \\
(0.0550)\end{array}$ \\
\hline Unemployed x Gini & $\begin{array}{l}-0.0604 \\
(0.0407)\end{array}$ & $\begin{array}{c}-0.0276 \\
(0.0286)\end{array}$ & $\begin{array}{c}-0.0437 \\
(0.0442)\end{array}$ & $\begin{array}{c}-0.0561 \\
(0.0443)\end{array}$ \\
\hline Observations & 12,398 & 12,398 & $\begin{array}{c}12,398 \\
\text { Yes }\end{array}$ & $\begin{array}{c}12,398 \\
\text { Yes }\end{array}$ \\
\hline
\end{tabular}

Note: Results from Equation (2) where the dependent variable is an indicator that equals 1 for strong concern about social problems and interaction term Gini is a dummy that equals 1 for above median inequality as measured by the Gini Index. Errors are clustered at the country-level and regressions are weighted by public weights provided in the survey. ${ }^{* *} p<0.01,{ }^{* *} p<0.05$ and ${ }^{*} p<0.1$ 
Table 14: Policy Preferences, Baseline

\begin{tabular}{|c|c|c|c|c|c|c|c|c|}
\hline & $\begin{array}{l}\text { (1) } \\
\text { Give financial } \\
\text { relief }\end{array}$ & $\begin{array}{l}\text { (2) } \\
\text { Give financial } \\
\text { relief }\end{array}$ & $\begin{array}{c}\text { (3) } \\
\text { Support small } \\
\text { business }\end{array}$ & $\begin{array}{c}\text { (4) } \\
\text { Support small } \\
\text { business }\end{array}$ & $\begin{array}{c}\text { (5) } \\
\text { Manage virus } \\
\text { spread }\end{array}$ & $\begin{array}{c}\text { (6) } \\
\text { Manage virus } \\
\text { spread }\end{array}$ & $\begin{array}{l}\text { (7) } \\
\text { Prep for } \\
\text { reopening }\end{array}$ & $\begin{array}{l}(8) \\
\text { Prep for } \\
\text { reopening }\end{array}$ \\
\hline Female & $\begin{array}{l}-0.00691 \\
(0.0136)\end{array}$ & $\begin{array}{l}-0.00306 \\
(0.0178)\end{array}$ & $\begin{array}{l}-0.00169 \\
(0.0173)\end{array}$ & $\begin{array}{l}0.00861 \\
(0.0239)\end{array}$ & $\begin{array}{c}-0.0155 \\
(0.0190)\end{array}$ & $\begin{array}{c}-0.0213 \\
(0.0270)\end{array}$ & $\begin{array}{c}-0.00430 \\
(0.0165)\end{array}$ & $\begin{array}{c}-0.0140 \\
(0.0202)\end{array}$ \\
\hline Young & $\begin{array}{l}-0.0533^{*} \\
(0.0285)\end{array}$ & $\begin{array}{l}-0.0455 \\
(0.0310)\end{array}$ & $\begin{array}{c}-0.0631^{* * *} \\
(0.0254)\end{array}$ & $\begin{array}{c}-0.0471^{*} \\
(0.0248)\end{array}$ & $\begin{array}{c}-0.0364 \\
(0.0289)\end{array}$ & $\begin{array}{l}-0.0408 \\
(0.0257)\end{array}$ & $\begin{array}{l}-0.0445 \\
(0.0345)\end{array}$ & $\begin{array}{l}-0.0498 \\
(0.0337)\end{array}$ \\
\hline College & $\begin{array}{c}0.0332 \\
(0.0229)\end{array}$ & $\begin{array}{c}0.0240 \\
(0.0227)\end{array}$ & $\begin{array}{l}0.0365^{*} \\
(0.0192)\end{array}$ & $\begin{array}{c}0.0214 \\
(0.0204)\end{array}$ & $\begin{array}{l}0.0430^{*} \\
(0.0195)\end{array}$ & $\begin{array}{l}0.0394^{*} \\
(0.0190)\end{array}$ & $\begin{array}{c}0.0438 \\
(0.0253)\end{array}$ & $\begin{array}{l}0.0505^{*} \\
(0.0264)\end{array}$ \\
\hline Urban & $\begin{array}{c}-0.0487^{* *} \\
(0.0181)\end{array}$ & $\begin{array}{c}-0.0764^{* * * *} \\
(0.0197)\end{array}$ & $\begin{array}{c}-0.0514^{* * *} \\
(0.0183)\end{array}$ & $\begin{array}{c}-0.0821^{* * * *} \\
(0.0177)\end{array}$ & $\begin{array}{l}-0.0331 \\
(0.0221)\end{array}$ & $\begin{array}{c}-0.0551^{* *} \\
(0.0241)\end{array}$ & $\begin{array}{c}-0.0566^{* * *} \\
(0.0188)\end{array}$ & $\begin{array}{c}-0.0763^{* * * *} \\
(0.0232)\end{array}$ \\
\hline Rich & $\begin{array}{c}-0.0194 \\
(0.0183)\end{array}$ & $\begin{array}{c}0.0131 \\
(0.0185)\end{array}$ & $\begin{array}{c}-0.0182 \\
(0.0163)\end{array}$ & $\begin{array}{c}0.0100 \\
(0.0179)\end{array}$ & $\begin{array}{l}-0.00260 \\
(0.0227)\end{array}$ & $\begin{array}{c}0.0143 \\
(0.0216)\end{array}$ & $\begin{array}{c}-0.0165 \\
(0.0250)\end{array}$ & $\begin{array}{l}0.00345 \\
(0.0256)\end{array}$ \\
\hline Unemp & $\begin{array}{r}-0.00465 \\
(0.0169)\end{array}$ & $\begin{array}{c}0.0584 \\
(0.0343)\end{array}$ & $\begin{array}{c}-0.000478 \\
(0.0160)\end{array}$ & $\begin{array}{c}0.0443 \\
(0.0309)\end{array}$ & $\begin{array}{c}0.0116 \\
(0.0156)\end{array}$ & $\begin{array}{c}0.0442 \\
(0.0263)\end{array}$ & $\begin{array}{l}0.0365^{*} \\
(0.0197)\end{array}$ & $\begin{array}{c}0.0536 \\
(0.0345)\end{array}$ \\
\hline Small Firm & & $\begin{array}{c}0.0906^{* * *} * \\
(0.0200)\end{array}$ & & $\begin{array}{c}0.0736^{* * *} \\
(0.0184)\end{array}$ & & $\begin{array}{c}0.0694^{* * *} * \\
(0.0194)\end{array}$ & & $\begin{array}{c}0.0794^{* * *} * \\
(0.0210)\end{array}$ \\
\hline Telework & & $\begin{array}{l}0.0211^{*} \\
(0.0107)\end{array}$ & & $\begin{array}{c}0.0105 \\
(0.0122)\end{array}$ & & $\begin{array}{c}0.0219 \\
(0.0152)\end{array}$ & & $\begin{array}{l}0.00826 \\
(0.0162)\end{array}$ \\
\hline $\begin{array}{l}\text { Observations } \\
\text { Country FE }\end{array}$ & $\begin{array}{c}12,398 \\
\text { Yes }\end{array}$ & $\begin{array}{l}7,047 \\
\text { Yes }\end{array}$ & $\begin{array}{c}12,398 \\
\text { Yes }\end{array}$ & $\begin{array}{l}7,047 \\
\text { Yes }\end{array}$ & $\begin{array}{c}12,398 \\
\text { Yes }\end{array}$ & $\begin{array}{c}7,047 \\
\text { Yes }\end{array}$ & $\begin{array}{c}12,398 \\
\text { Yes }\end{array}$ & $\begin{array}{l}7,047 \\
\text { Yes }\end{array}$ \\
\hline
\end{tabular}

Note: Results from Equation (1) where the dependent variable is an indicator that equals 1 for expectation for government playing a leading role in the specified policy measures. Errors are clustered at the country-level and regressions are weighted by public weights provided in the survey. ${ }^{* *} p<0.01,{ }^{* *} p<0.05$ and ${ }^{*} p<0.1$

\begin{tabular}{|c|c|c|c|c|c|c|c|c|}
\hline & $\begin{array}{c}\text { (1) } \\
\text { Give } \\
\text { financial } \\
\text { relief }\end{array}$ & $\begin{array}{c}\text { (2) } \\
\text { Give } \\
\text { financial } \\
\text { relief }\end{array}$ & $\begin{array}{c}\text { (3) } \\
\text { Support small } \\
\text { business }\end{array}$ & $\begin{array}{c}\text { (4) } \\
\text { Support small } \\
\text { business }\end{array}$ & $\begin{array}{c}\text { (5) } \\
\text { Manage virus } \\
\text { spread }\end{array}$ & $\begin{array}{c}(6) \\
\text { Manage virus } \\
\text { spread }\end{array}$ & $\begin{array}{c}\text { (7) } \\
\text { Prep for } \\
\text { reopening }\end{array}$ & $\begin{array}{c}\text { (8) } \\
\text { Prep for } \\
\text { reopening }\end{array}$ \\
\hline Lost Job & $\begin{array}{c}0.0470 \\
(0.0289)\end{array}$ & & $\begin{array}{c}0.0326 \\
(0.0264)\end{array}$ & & $\begin{array}{c}0.0317 \\
(0.0234)\end{array}$ & & $\begin{array}{c}0.0375 \\
(0.0307)\end{array}$ & \\
\hline Infected & & $\begin{array}{c}-0.133^{* * *} \\
(0.0397)\end{array}$ & & $\begin{array}{l}-0.138^{* * *} \\
(0.0322)\end{array}$ & & $\begin{array}{l}-0.126^{* *} \\
(0.0441)\end{array}$ & & $\begin{array}{c}-0.179^{* * *} \\
(0.0390)\end{array}$ \\
\hline $\begin{array}{l}\text { Observations } \\
\text { Country FE }\end{array}$ & $\begin{array}{c}12,416 \\
\text { Yes }\end{array}$ & $\begin{array}{c}12,416 \\
\text { Yes }\end{array}$ & $\begin{array}{c}12,416 \\
\text { Yes }\end{array}$ & $\begin{array}{c}12,416 \\
\text { Yes }\end{array}$ & $\begin{array}{c}12,416 \\
\text { Yes }\end{array}$ & $\begin{array}{c}12,416 \\
0.043\end{array}$ & $\begin{array}{c}12,416 \\
0.047\end{array}$ & $\begin{array}{c}12,416 \\
0.063\end{array}$ \\
\hline \multicolumn{9}{|c|}{$\begin{array}{l}\text { Note: Results from Equation (1) where the dependent variable is an indicator that equals } 1 \text { for expectation for } \\
\text { government playing a leading role in the specified policy measures. Individual controls include gender, age, urban, } \\
\text { education, employment status and household income dummies. Errors are clustered at the country-level and } \\
\text { regressions are weighted by public weights provided in the survey. }{ }^{* *} p<0.01,{ }^{* *} p<0.05 \text { and }{ }^{*} p<0.1\end{array}$} \\
\hline
\end{tabular}


Table 16: Policy preferences by Assessment of Government Performance

\begin{tabular}{lcccc}
\hline & $(1)$ & $(2)$ & $(3)$ & $(4)$ \\
& Given financial relief & $\begin{array}{c}\text { Support small } \\
\text { business }\end{array}$ & $\begin{array}{c}\text { Manage virus spread } \\
\text { Prep for reopening }\end{array}$ \\
Overall Performance & $0.0782^{* * *}$ & $0.0817 * *$ & $0.0863 * * *$ & $0.105^{* * *}$ \\
Observations & $(0.0241)$ & $(0.0261)$ & $(0.0248)$ & $(0.0264)$ \\
Individual controls & 12,398 & 12,398 & 12,398 & 12,398 \\
Country FE & Yes & Yes & Yes & Yes \\
\hline
\end{tabular}

Note: Results from Equation (1) where the dependent variable is an indicator that equals 1 for expectation for government playing a leading role in the specified policy measures. Overall performance is an indicator that equals 1 for favorable assessment of overall government performance during COVID-19 crisis. Individual controls include gender, age, urban, education, employment status and household income dummies. Errors are clustered at the country-level and regressions are weighted by public weights provided in the survey. ${ }^{* *} p<0.01,{ }^{* *} p<0.05$ and ${ }^{*} p<0.1$

\section{Table 17: Policy Preferences, Advanced vs Emerging Market Economies}

\begin{tabular}{|c|c|c|c|c|}
\hline & $\begin{array}{l}\text { (1) } \\
\text { Given financial } \\
\text { relief }\end{array}$ & $\begin{array}{c}\text { (2) } \\
\text { Support small business }\end{array}$ & $\begin{array}{c}\text { (3) } \\
\text { Manage virus spread }\end{array}$ & $\begin{array}{c}\text { (4) } \\
\text { Prep for reopening }\end{array}$ \\
\hline Female & $\begin{array}{l}-0.00732 \\
(0.0173)\end{array}$ & $\begin{array}{c}-0.000552 \\
(0.0206)\end{array}$ & $\begin{array}{l}-0.0210 \\
(0.0215)\end{array}$ & $\begin{array}{l}0.00147 \\
(0.0227)\end{array}$ \\
\hline Young & $\begin{array}{c}-0.0994 * * * \\
(0.0195)\end{array}$ & $\begin{array}{c}-0.0951^{* * * *} \\
(0.0171)\end{array}$ & $\begin{array}{l}-0.0750 * * \\
(0.0296)\end{array}$ & $\begin{array}{l}-0.101^{* * * *} \\
(0.0271)\end{array}$ \\
\hline College & $\begin{array}{c}0.0144 \\
(0.0135)\end{array}$ & $\begin{array}{c}0.0294 \\
(0.0170)\end{array}$ & $\begin{array}{l}0.0283^{*} \\
(0.0143)\end{array}$ & $\begin{array}{l}0.0296^{*} \\
(0.0151)\end{array}$ \\
\hline Urban & $\begin{array}{c}-0.0562^{* * *} \\
(0.0183)\end{array}$ & $\begin{array}{c}-0.0660 * * * * \\
(0.0191)\end{array}$ & $\begin{array}{l}-0.0489 * * \\
(0.0203)\end{array}$ & $\begin{array}{c}-0.0717^{* * * *} \\
(0.0165)\end{array}$ \\
\hline Rich & $\begin{array}{l}-0.000498 \\
(0.0175)\end{array}$ & $\begin{array}{l}-0.00367 \\
(0.0122)\end{array}$ & $\begin{array}{c}0.0254 \\
(0.0188)\end{array}$ & $\begin{array}{c}0.0224 \\
(0.0245)\end{array}$ \\
\hline Unemployed & $\begin{array}{l}-0.0133 \\
(0.0171)\end{array}$ & $\begin{array}{l}0.00432 \\
(0.0111)\end{array}$ & $\begin{array}{l}-0.00146 \\
(0.0145)\end{array}$ & $\begin{array}{l}0.0147 * * \\
(0.00548)\end{array}$ \\
\hline Female $x$ EM & $\begin{array}{l}0.00166 \\
(0.0283)\end{array}$ & $\begin{array}{l}-0.00225 \\
(0.0357)\end{array}$ & $\begin{array}{c}0.0167 \\
(0.0396)\end{array}$ & $\begin{array}{l}-0.0109 \\
(0.0323)\end{array}$ \\
\hline Young $\mathrm{x}$ EM & $\begin{array}{l}0.103 * \\
(0.0494)\end{array}$ & $\begin{array}{c}0.0711 \\
(0.0475)\end{array}$ & $\begin{array}{c}0.0862 \\
(0.0529)\end{array}$ & $\begin{array}{c}0.124^{*} \\
(0.0596)\end{array}$ \\
\hline College x EM & $\begin{array}{c}0.0511 \\
(0.0496)\end{array}$ & $\begin{array}{c}0.0165 \\
(0.0405)\end{array}$ & $\begin{array}{c}0.0354 \\
(0.0404)\end{array}$ & $\begin{array}{c}0.0351 \\
(0.0579)\end{array}$ \\
\hline Urban $x$ EM & $\begin{array}{c}0.0545 \\
(0.0414)\end{array}$ & $\begin{array}{l}0.0856 * * \\
(0.0299)\end{array}$ & $\begin{array}{l}0.0973^{*} \\
(0.0515)\end{array}$ & $\begin{array}{l}0.103^{* * *} \\
(0.0420)\end{array}$ \\
\hline Rich x EM & $\begin{array}{l}-0.0503 \\
(0.0365)\end{array}$ & $\begin{array}{l}-0.0415 \\
(0.0363)\end{array}$ & $\begin{array}{l}-0.0777 \\
(0.0445)\end{array}$ & $\begin{array}{l}-0.104 * * \\
(0.0370)\end{array}$ \\
\hline Unemployed x EM & $\begin{array}{c}0.0417 \\
(0.0413)\end{array}$ & $\begin{array}{l}-0.00545 \\
(0.0461)\end{array}$ & $\begin{array}{c}0.0592 \\
(0.0331)\end{array}$ & $\begin{array}{c}0.0944 \\
(0.0630)\end{array}$ \\
\hline $\begin{array}{l}\text { Observations } \\
\text { Country FE }\end{array}$ & $\begin{array}{c}12,398 \\
\text { Yes }\end{array}$ & $\begin{array}{c}12,398 \\
\text { Yes }\end{array}$ & $\begin{array}{c}12,398 \\
\text { Yes }\end{array}$ & $\begin{array}{c}12,398 \\
\text { Yes }\end{array}$ \\
\hline
\end{tabular}

Note: Results from Equation (2) where the dependent variable is an indicator that equals 1 for expectation for government playing a leading role in the specified policy measures and interaction term $E M$ is a dummy that equals 1 for emerging economics and 0 otherwise. Errors are clustered at the country-level and regressions are weighted by public weights provided in the survey. ${ }^{* *} p<0.01,{ }^{* *} p<0.05$ and ${ }^{*} p<0.1$ 
Table 18: Policy Preferences by Stringency of Containment Measures

\begin{tabular}{|c|c|c|c|c|}
\hline & $\begin{array}{l}\text { (1) } \\
\text { Given financial } \\
\text { relief }\end{array}$ & $\begin{array}{c}\text { (2) } \\
\text { Support small business }\end{array}$ & $\begin{array}{l}\text { (3) } \\
\text { Manage virus spread }\end{array}$ & $\begin{array}{c}(4) \\
\text { Prep for reopening }\end{array}$ \\
\hline Female & $\begin{array}{l}0.00441 \\
(0.0169)\end{array}$ & $\begin{array}{c}0.0197 \\
(0.0183)\end{array}$ & $\begin{array}{l}0.00167 \\
(0.0194)\end{array}$ & $\begin{array}{c}0.0136 \\
(0.0183)\end{array}$ \\
\hline Young & $\begin{array}{l}-0.0685 \\
(0.0437)\end{array}$ & $\begin{array}{l}-0.0716^{*} \\
(0.0351)\end{array}$ & $\begin{array}{l}-0.0554 \\
(0.0432)\end{array}$ & $\begin{array}{l}-0.0658 \\
(0.0551)\end{array}$ \\
\hline College & $\begin{array}{c}0.0370 \\
(0.0326)\end{array}$ & $\begin{array}{c}0.0410 \\
(0.0251)\end{array}$ & $\begin{array}{c}0.0499 \\
(0.0281)\end{array}$ & $\begin{array}{c}0.0535 \\
(0.0344)\end{array}$ \\
\hline Urban & $\begin{array}{c}-0.0569 * * \\
(0.0206)\end{array}$ & $\begin{array}{c}-0.0704 * * * \\
(0.0186)\end{array}$ & $\begin{array}{l}-0.0447 \\
(0.0253)\end{array}$ & $\begin{array}{c}-0.0698 * * * \\
(0.0202)\end{array}$ \\
\hline Rich & $\begin{array}{l}-0.0204 \\
(0.0252)\end{array}$ & $\begin{array}{l}-0.0222 \\
(0.0232)\end{array}$ & $\begin{array}{l}0.00554 \\
(0.0265)\end{array}$ & $\begin{array}{c}-0.000896 \\
(0.0348)\end{array}$ \\
\hline Unemployed & $\begin{array}{l}-0.0131 \\
(0.0193)\end{array}$ & $\begin{array}{c}-0.000234 \\
(0.0151)\end{array}$ & $\begin{array}{l}-0.0153 \\
(0.0167)\end{array}$ & $\begin{array}{l}0.0130 * * \\
(0.00557)\end{array}$ \\
\hline Female $\mathrm{x}$ Stringent & $\begin{array}{l}-0.0312 \\
(0.0265)\end{array}$ & $\begin{array}{l}-0.0601^{*} \\
(0.0314)\end{array}$ & $\begin{array}{l}-0.0469 \\
(0.0405)\end{array}$ & $\begin{array}{l}-0.0482 \\
(0.0323)\end{array}$ \\
\hline Young $x$ Stringent & $\begin{array}{c}0.0350 \\
(0.0516)\end{array}$ & $\begin{array}{c}0.0212 \\
(0.0475)\end{array}$ & $\begin{array}{c}0.0429 \\
(0.0529)\end{array}$ & $\begin{array}{c}0.0470 \\
(0.0610)\end{array}$ \\
\hline College $\mathrm{x}$ Stringent & $\begin{array}{l}-0.00807 \\
(0.0388)\end{array}$ & $\begin{array}{l}-0.00902 \\
(0.0375)\end{array}$ & $\begin{array}{l}-0.0167 \\
(0.0326)\end{array}$ & $\begin{array}{l}-0.0250 \\
(0.0459)\end{array}$ \\
\hline Urban $x$ Stringent & $\begin{array}{c}0.0334 \\
(0.0268)\end{array}$ & $\begin{array}{l}0.0730 * * * \\
(0.0214)\end{array}$ & $\begin{array}{c}0.0479 \\
(0.0301)\end{array}$ & $\begin{array}{l}0.0547^{* * *} \\
(0.0245)\end{array}$ \\
\hline Rich $x$ Stringent & $\begin{array}{l}0.00186 \\
(0.0347)\end{array}$ & $\begin{array}{l}0.00929 \\
(0.0284)\end{array}$ & $\begin{array}{l}-0.0241 \\
(0.0479)\end{array}$ & $\begin{array}{l}-0.0454 \\
(0.0416)\end{array}$ \\
\hline Unemployed $\mathrm{x}$ Stringent & $\begin{array}{c}0.0247 \\
(0.0378)\end{array}$ & $\begin{array}{l}0.00244 \\
(0.0371)\end{array}$ & $\begin{array}{l}0.0740 * * \\
(0.0281)\end{array}$ & $\begin{array}{c}0.0649 \\
(0.0477)\end{array}$ \\
\hline $\begin{array}{l}\text { Observations } \\
\text { Country FE }\end{array}$ & $\begin{array}{c}12,398 \\
0.052\end{array}$ & $\begin{array}{c}12,398 \\
0.047\end{array}$ & $\begin{array}{c}12,398 \\
0.037\end{array}$ & $\begin{array}{c}12,398 \\
0.050\end{array}$ \\
\hline
\end{tabular}

Note: Results from Equation (2) where the dependent variable is an indicator that equals 1 for expectation for government playing a leading role in the specified policy measures and interaction term Stringent is a dummy that equals 1 for above the median stringency index in OxCGRT. Errors are clustered at the country-level and regressions are weighted by public weights provided in the survey. ${ }^{* * *} p<0.01,{ }^{* *} p<0.05$ and ${ }^{*} p<0.1$ 


\begin{tabular}{|c|c|c|c|c|}
\hline \multicolumn{5}{|c|}{ Table 19: Policy Preferences by Timing of COVID-19 Spread } \\
\hline & $\begin{array}{c}\text { (1) } \\
\text { Give financial relief }\end{array}$ & $\begin{array}{c}\text { (2) } \\
\text { Support small business }\end{array}$ & $\begin{array}{c}\text { (3) } \\
\text { Manage virus spread }\end{array}$ & $\begin{array}{c}\text { (4) } \\
\text { Prep for reopening }\end{array}$ \\
\hline Female & $\begin{array}{c}-0.00979 \\
(0.0152)\end{array}$ & $\begin{array}{l}-0.00681 \\
(0.0191)\end{array}$ & $\begin{array}{c}-0.0200 \\
(0.0209)\end{array}$ & $\begin{array}{l}-0.00924 \\
(0.0198)\end{array}$ \\
\hline Young & $\begin{array}{c}-0.0782^{* * *} \\
(0.0231)\end{array}$ & $\begin{array}{c}-0.0840^{* * *} \\
(0.0226)\end{array}$ & $\begin{array}{l}-0.0561^{*} \\
(0.0265)\end{array}$ & $\begin{array}{c}-0.0743^{* *} \\
(0.0268)\end{array}$ \\
\hline College & $\begin{array}{c}0.0119 \\
(0.0115)\end{array}$ & $\begin{array}{c}0.0177 \\
(0.0149)\end{array}$ & $\begin{array}{l}0.0228^{*} \\
(0.0124)\end{array}$ & $\begin{array}{c}0.0188 \\
(0.0147)\end{array}$ \\
\hline Urban & $\begin{array}{c}-0.0597^{* * *} \\
(0.0171)\end{array}$ & $\begin{array}{l}-0.0552^{* 8} \\
(0.0183)\end{array}$ & $\begin{array}{l}-0.0437^{*} \\
(0.0201)\end{array}$ & $\begin{array}{c}-0.0645^{* * *} * \\
(0.0169)\end{array}$ \\
\hline Rich & $\begin{array}{l}-0.0146 \\
(0.0159)\end{array}$ & $\begin{array}{l}-0.00936 \\
(0.0110)\end{array}$ & $\begin{array}{l}0.00156 \\
(0.0236)\end{array}$ & $\begin{array}{l}-0.00815 \\
(0.0246)\end{array}$ \\
\hline Unemployed & $\begin{array}{l}0.000997 \\
(0.0176)\end{array}$ & $\begin{array}{l}0.00495 \\
(0.0167)\end{array}$ & $\begin{array}{c}0.0238 \\
(0.0141)\end{array}$ & $\begin{array}{c}0.0341 \\
(0.0212)\end{array}$ \\
\hline Female $\mathrm{x}$ Down & $\begin{array}{l}0.00263 \\
(0.0290)\end{array}$ & $\begin{array}{c}0.0195 \\
(0.0399)\end{array}$ & $\begin{array}{c}0.0122 \\
(0.0434)\end{array}$ & $\begin{array}{c}0.0140 \\
(0.0199)\end{array}$ \\
\hline Young x Down & $\begin{array}{l}0.141^{8 *} \\
(0.0552)\end{array}$ & $\begin{array}{l}0.116^{* *} \\
(0.0471)\end{array}$ & $\begin{array}{c}0.111 \\
(0.0630)\end{array}$ & $\begin{array}{c}0.166^{*} \\
(0.0817)\end{array}$ \\
\hline College x Down & $\begin{array}{l}0.0925 \\
(0.0577)\end{array}$ & $\begin{array}{l}0.0833^{* *} \\
(0.0291)\end{array}$ & $\begin{array}{l}0.0892^{* 8} \\
(0.0310)\end{array}$ & $\begin{array}{c}0.110^{*} \\
(0.0527)\end{array}$ \\
\hline Urban x Down & $\begin{array}{l}0.102^{* * *} \\
(0.0272)\end{array}$ & $\begin{array}{c}0.0393 \\
(0.0555)\end{array}$ & $\begin{array}{c}0.0952 \\
(0.0728)\end{array}$ & $\begin{array}{c}0.0805 \\
(0.0627)\end{array}$ \\
\hline Rich $x$ Down & $\begin{array}{l}-0.0285 \\
(0.0629)\end{array}$ & $\begin{array}{l}-0.0457 \\
(0.0639)\end{array}$ & $\begin{array}{l}-0.0256 \\
(0.0682)\end{array}$ & $\begin{array}{l}-0.0445 \\
(0.0719)\end{array}$ \\
\hline Unemp $\mathrm{x}$ Down & $\begin{array}{l}-0.0649 * * \\
(0.0232)\end{array}$ & $\begin{array}{l}-0.0617^{*} \\
(0.0280)\end{array}$ & $\begin{array}{l}-0.136^{* * *} \\
(0.0283)\end{array}$ & $\begin{array}{c}0.0219 \\
(0.0482)\end{array}$ \\
\hline $\begin{array}{l}\text { Observations } \\
\text { Country FE }\end{array}$ & $\begin{array}{c}12,398 \\
\text { Yes }\end{array}$ & $\begin{array}{c}12,398 \\
\text { Yes }\end{array}$ & $\begin{array}{c}12,398 \\
\text { Yes }\end{array}$ & $\begin{array}{c}12,398 \\
\text { Yes }\end{array}$ \\
\hline $\begin{array}{l}\text { te: Results from } E \\
\text { ernment playing } \\
\text { tals } 1 \text { for countrie } \\
\text { vey. Errors are clu } \\
\text { vey. }{ }^{* * *} \mathrm{p}<0.01 \text {, }{ }^{* *}\end{array}$ & $\begin{array}{l}\text { hat saw an initial surg } \\
\text { red at the country-le } \\
0.05 \text { and }{ }^{*} p<0.1\end{array}$ & $\begin{array}{l}\text { el and regressions are we } \\
\text { ellowed by a downwar }\end{array}$ & $\begin{array}{l}\text { licator that equals } 1 \text { fo } \\
\text { interaction term Dow } \\
\text { trend in COVID-19 ca } \\
\text { ighted by public weigh }\end{array}$ & $\begin{array}{l}\text { expectation for } \\
\mathrm{n} \text { is a dummy that } \\
\text { ses at the time of } \\
\text { ts provided in the }\end{array}$ \\
\hline
\end{tabular}

(C)International Monetary Fund. Not for Redistribution 
Table 20: Policy Preferences by Initial Level of Inequality

\begin{tabular}{|c|c|c|c|c|}
\hline & $\begin{array}{l}\text { (1) } \\
\text { Given financial relief }\end{array}$ & $\begin{array}{c}(2) \\
\text { Support small business }\end{array}$ & $\begin{array}{c}\text { (3) } \\
\text { Manage virus spread }\end{array}$ & $\begin{array}{c}\text { (4) } \\
\text { Prep for reopening }\end{array}$ \\
\hline Female & $\begin{array}{l}-0.0169 \\
(0.0145)\end{array}$ & $\begin{array}{l}-0.00436 \\
(0.0201)\end{array}$ & $\begin{array}{l}-0.0257 \\
(0.0189)\end{array}$ & $\begin{array}{l}-0.00893 \\
(0.0207)\end{array}$ \\
\hline Young & $\begin{array}{c}-0.0809 * * * \\
(0.0236)\end{array}$ & $\begin{array}{c}-0.0894 * * * \\
(0.0172)\end{array}$ & $\begin{array}{l}-0.0573 \\
(0.0333)\end{array}$ & $\begin{array}{l}-0.0687^{*} \\
(0.0314)\end{array}$ \\
\hline College & $\begin{array}{c}0.0138 \\
(0.0143)\end{array}$ & $\begin{array}{c}0.0255 \\
(0.0189)\end{array}$ & $\begin{array}{c}0.0276 \\
(0.0154)\end{array}$ & $\begin{array}{c}0.0225 \\
(0.0181)\end{array}$ \\
\hline Urban & $\begin{array}{c}-0.0491 * * \\
(0.0176)\end{array}$ & $\begin{array}{c}-0.0512 * * * \\
(0.0160)\end{array}$ & $\begin{array}{l}-0.0377 \\
(0.0212)\end{array}$ & $\begin{array}{c}-0.0664^{* * * *} \\
(0.0177)\end{array}$ \\
\hline Rich & $\begin{array}{l}-0.0121 \\
(0.0169)\end{array}$ & $\begin{array}{c}-0.000599 \\
(0.0125)\end{array}$ & $\begin{array}{l}0.00637 \\
(0.0136)\end{array}$ & $\begin{array}{l}-0.00739 \\
(0.0171)\end{array}$ \\
\hline Unemployed & $\begin{array}{l}-0.0203 \\
(0.0160)\end{array}$ & $\begin{array}{l}-9.72 \mathrm{e}-05 \\
(0.00954)\end{array}$ & $\begin{array}{l}0.00854 \\
(0.0217)\end{array}$ & $\begin{array}{c}0.0287 \\
(0.0179)\end{array}$ \\
\hline Female $x$ Gini & $\begin{array}{c}0.0266 \\
(0.0304)\end{array}$ & $\begin{array}{l}0.00807 \\
(0.0376)\end{array}$ & $\begin{array}{c}0.0272 \\
(0.0425)\end{array}$ & $\begin{array}{c}0.0115 \\
(0.0352)\end{array}$ \\
\hline Young x Gini & $\begin{array}{c}0.0671 \\
(0.0589)\end{array}$ & $\begin{array}{c}0.0620 \\
(0.0523)\end{array}$ & $\begin{array}{c}0.0502 \\
(0.0592)\end{array}$ & $\begin{array}{c}0.0582 \\
(0.0721)\end{array}$ \\
\hline College x Gini & $\begin{array}{c}0.0503 \\
(0.0492)\end{array}$ & $\begin{array}{c}0.0291 \\
(0.0395)\end{array}$ & $\begin{array}{c}0.0395 \\
(0.0402)\end{array}$ & $\begin{array}{c}0.0548 \\
(0.0544)\end{array}$ \\
\hline Urban x Gini & $\begin{array}{l}0.00414 \\
(0.0520)\end{array}$ & $\begin{array}{c}-9.27 \mathrm{e}-06 \\
(0.0580)\end{array}$ & $\begin{array}{c}0.0197 \\
(0.0648)\end{array}$ & $\begin{array}{c}0.0415 \\
(0.0591)\end{array}$ \\
\hline Rich x Gini & $\begin{array}{l}-0.0188 \\
(0.0427)\end{array}$ & $\begin{array}{l}-0.0442 \\
(0.0339)\end{array}$ & $\begin{array}{l}-0.0230 \\
(0.0564)\end{array}$ & $\begin{array}{l}-0.0235 \\
(0.0606)\end{array}$ \\
\hline Unemployed x Gini & $\begin{array}{c}0.0454 \\
(0.0312)\end{array}$ & $\begin{array}{l}0.00271 \\
(0.0359)\end{array}$ & $\begin{array}{c}0.0123 \\
(0.0252)\end{array}$ & $\begin{array}{c}0.0271 \\
(0.0463)\end{array}$ \\
\hline $\begin{array}{l}\text { Observations } \\
\text { Country FE }\end{array}$ & $\begin{array}{c}12,398 \\
\text { Yes }\end{array}$ & $\begin{array}{c}12,398 \\
\text { Yes }\end{array}$ & $\begin{array}{c}12,398 \\
\text { Yes }\end{array}$ & $\begin{array}{c}12,398 \\
\text { Yes }\end{array}$ \\
\hline
\end{tabular}

Note: Results from Equation (2) where the dependent variable is an indicator that equals 1 for expectation for government playing a leading role in the specified policy measures and interaction term Gini is a dummy that equals 1 for above median inequality as measured by the Gini Index. Errors are clustered at the country-level and regressions are weighted by public weights provided in the survey. ${ }^{* *} p<0.01,{ }^{* *} p<0.05$ and ${ }^{*} p<0.1$ 
Robustness Checks

\begin{tabular}{|c|c|c|c|c|c|c|}
\hline & $\begin{array}{c}(1) \\
\text { Overall }\end{array}$ & $\begin{array}{c}(2) \\
\text { Overall }\end{array}$ & $\begin{array}{c}(3) \\
\text { Health }\end{array}$ & $\begin{array}{c}(4) \\
\text { Health }\end{array}$ & $\begin{array}{c}5) \\
\text { Economic }\end{array}$ & $\begin{array}{c}(6) \\
\text { Economic }\end{array}$ \\
\hline Female & $\begin{array}{l}-0.0631^{*} \\
(0.0354)\end{array}$ & $\begin{array}{c}-0.0996 * * \\
(0.0401)\end{array}$ & $\begin{array}{c}-0.130 * * * \\
(0.0423)\end{array}$ & $\begin{array}{c}-0.164 * * * \\
(0.0484)\end{array}$ & $\begin{array}{c}-0.140 * * * \\
(0.0351)\end{array}$ & $\begin{array}{c}-0.134 * * * \\
(0.0414)\end{array}$ \\
\hline Young & $\begin{array}{l}-0.00472 \\
(0.0462)\end{array}$ & $\begin{array}{c}0.0506 \\
(0.0329)\end{array}$ & $\begin{array}{l}-0.0170 \\
(0.0645)\end{array}$ & $\begin{array}{c}0.000397 \\
(0.0748)\end{array}$ & $\begin{array}{l}-0.0682 \\
(0.0468)\end{array}$ & $\begin{array}{r}-0.00907 \\
(0.0476)\end{array}$ \\
\hline College & $\begin{array}{c}0.0402 \\
(0.0328)\end{array}$ & $\begin{array}{c}0.0264 \\
(0.0411)\end{array}$ & $\begin{array}{c}0.0545 \\
(0.0430)\end{array}$ & $\begin{array}{c}0.0503 \\
(0.0570)\end{array}$ & $\begin{array}{c}0.0421 \\
(0.0331)\end{array}$ & $\begin{array}{l}0.0966^{*} \\
(0.0498)\end{array}$ \\
\hline Urban & $\begin{array}{c}0.0187 \\
(0.0311)\end{array}$ & $\begin{array}{c}0.0222 \\
(0.0559)\end{array}$ & $\begin{array}{c}0.116 * * * \\
(0.0256)\end{array}$ & $\begin{array}{c}0.133 * * * \\
(0.0511)\end{array}$ & $\begin{array}{c}0.0528 \\
(0.0414)\end{array}$ & $\begin{array}{c}0.0519 \\
(0.0706)\end{array}$ \\
\hline Rich & $\begin{array}{c}0.0178 \\
(0.0435)\end{array}$ & $\begin{array}{c}0.0560 \\
(0.0446)\end{array}$ & $\begin{array}{c}0.0221 \\
(0.0601)\end{array}$ & $\begin{array}{c}0.0229 \\
(0.0679)\end{array}$ & $\begin{array}{l}0.00873 \\
(0.0506)\end{array}$ & $\begin{array}{c}0.0292 \\
(0.0513)\end{array}$ \\
\hline Unemployed & $\begin{array}{l}-0.133 * * \\
(0.0622)\end{array}$ & $\begin{array}{c}-0.0772 \\
(0.131)\end{array}$ & $\begin{array}{l}-0.153 * * \\
(0.0604)\end{array}$ & $\begin{array}{c}-0.150 \\
(0.0928)\end{array}$ & $\begin{array}{c}-0.190 * * * \\
(0.0636)\end{array}$ & $\begin{array}{c}-0.0964 \\
(0.112)\end{array}$ \\
\hline Small Firm & & $\begin{array}{l}0.00225 \\
(0.0399)\end{array}$ & & $\begin{array}{l}-0.124^{* *} \\
(0.0606)\end{array}$ & & $\begin{array}{l}-0.0432 \\
(0.0607)\end{array}$ \\
\hline Tele-workable & & $\begin{array}{c}0.0689 * * \\
(0.0272)\end{array}$ & & $\begin{array}{c}0.0581 \\
(0.0425)\end{array}$ & & $\begin{array}{c}0.0348 \\
(0.0418)\end{array}$ \\
\hline Observations & 11,197 & 6,279 & 11,197 & 6,279 & 11,197 & 6,279 \\
\hline Country FE & Yes & Yes & Yes & Yes & Yes & Yes \\
\hline
\end{tabular}

\begin{tabular}{|c|c|c|c|c|}
\hline & $\begin{array}{c}\text { (1) } \\
\text { Vulnerable more affected }\end{array}$ & $\begin{array}{c}\text { (2) } \\
\text { Capitalism is harmful }\end{array}$ & $\begin{array}{c}\text { (3) } \\
\text { Prolonged job losses }\end{array}$ & $\begin{array}{c}\text { (4) } \\
\text { Threat of automation }\end{array}$ \\
\hline Female & $\begin{array}{l}0.109^{* * *} \\
(0.0450)\end{array}$ & $\begin{array}{c}0.0324 \\
(0.0356)\end{array}$ & $\begin{array}{c}0.0508 \\
(0.0436)\end{array}$ & $\begin{array}{c}0.0310 \\
(0.0414)\end{array}$ \\
\hline Young & $\begin{array}{l}-0.135^{\text {*冰* }} \\
(0.0415)\end{array}$ & $\begin{array}{l}-0.0918^{* * *} \\
(0.0426)\end{array}$ & $\begin{array}{l}-0.0235 \\
(0.0594)\end{array}$ & $\begin{array}{c}-0.143^{* k} \cdot k \\
(0.0565)\end{array}$ \\
\hline College & $\begin{array}{l}-0.00539 \\
(0.0337)\end{array}$ & $\begin{array}{l}-0.0668 \\
(0.0455)\end{array}$ & $\begin{array}{l}-0.0352 \\
(0.0484)\end{array}$ & $\begin{array}{l}-0.0483 \\
(0.0472)\end{array}$ \\
\hline Urban & $\begin{array}{l}0.122 * * \\
(0.0508)\end{array}$ & $\begin{array}{c}0.0781 \\
(0.0658)\end{array}$ & $\begin{array}{l}0.138^{* * k} \\
(0.0625)\end{array}$ & $\begin{array}{l}0.186^{* * * *} \\
(0.0564)\end{array}$ \\
\hline Rich & $\begin{array}{c}0.0456 \\
(0.0564)\end{array}$ & $\begin{array}{l}-0.0292 \\
(0.0686)\end{array}$ & $\begin{array}{c}0.0262 \\
(0.0509)\end{array}$ & $\begin{array}{c}0.0451 \\
(0.0775)\end{array}$ \\
\hline Unemployed & $\begin{array}{l}0.173^{*} \cdot k_{k} \cdot k \\
(0.0549)\end{array}$ & $\begin{array}{l}0.232^{* * * k} \\
(0.0430)\end{array}$ & $\begin{array}{l}0.290^{* * *} * \\
(0.0666)\end{array}$ & $\begin{array}{l}-0.0171 \\
(0.0635)\end{array}$ \\
\hline $\begin{array}{l}\text { Observations } \\
\text { Country FE }\end{array}$ & $\begin{array}{c}12,398 \\
\text { Yes }\end{array}$ & $\begin{array}{c}12,398 \\
\text { Yes }\end{array}$ & $\begin{array}{c}12,398 \\
\text { Yes }\end{array}$ & $\begin{array}{c}12,398 \\
\text { Yes }\end{array}$ \\
\hline $\begin{array}{l}\text { Note: Probit } r \\
\text { strong concer } \\
\text { at the country } \\
\text { and }{ }^{*} p<0.1\end{array}$ & $\begin{array}{l}\text { ession results from Equa } \\
\text { about socio-economic pr } \\
\text { el and regressions are }\end{array}$ & $\begin{array}{l}\text { (1) where the depen } \\
\text { lems (at least } 7 \text { on the } \\
\text { ghted by public weigh }\end{array}$ & $\begin{array}{l}\text { nt variable is an indi } \\
\text { cale of } 1-9 \text { in the sur } \\
\text { provided in the surve }\end{array}$ & $\begin{array}{l}\text { or that equals } 1 \text { for } \\
y \text { ). Errors are clustere } \\
{ }^{* \star} p<0.01,{ }^{* \star} p<0.05\end{array}$ \\
\hline
\end{tabular}


Table 23: Policy Preferences, Probit model

\begin{tabular}{|c|c|c|c|c|}
\hline & $\begin{array}{c}\text { (1) } \\
\text { Give financial relief }\end{array}$ & $\begin{array}{c}(2) \\
\text { Support small business }\end{array}$ & $\begin{array}{c}\text { (3) } \\
\text { Manage virus spread }\end{array}$ & $\begin{array}{c}(4) \\
\text { Prep for reopening }\end{array}$ \\
\hline Female & $\begin{array}{l}-0.0214 \\
(0.0420)\end{array}$ & $\begin{array}{l}-0.00482 \\
(0.0516)\end{array}$ & $\begin{array}{l}-0.0447 \\
(0.0527)\end{array}$ & $\begin{array}{l}-0.0125 \\
(0.0494)\end{array}$ \\
\hline Young & $\begin{array}{l}-0.161^{*} \\
(0.0827)\end{array}$ & $\begin{array}{l}-0.184 * * \\
(0.0717)\end{array}$ & $\begin{array}{c}-0.103 \\
(0.0790)\end{array}$ & $\begin{array}{c}-0.133 \\
(0.0973)\end{array}$ \\
\hline College & $\begin{array}{c}0.0977 \\
(0.0650)\end{array}$ & $\begin{array}{l}0.107 * * \\
(0.0539)\end{array}$ & $\begin{array}{l}0.119 * k \\
(0.0522)\end{array}$ & $\begin{array}{c}0.128^{*} \\
(0.0706)\end{array}$ \\
\hline Urban & 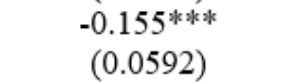 & $\begin{array}{l}-0.160^{* * k \cdot k} \\
(0.0573)\end{array}$ & $\begin{array}{l}-0.0955 \\
(0.0635)\end{array}$ & $\begin{array}{l}-0.173^{* * * * k} \\
(0.0589)\end{array}$ \\
\hline Rich & $\begin{array}{l}-0.0560 \\
(0.0537)\end{array}$ & $\begin{array}{l}-0.0523 \\
(0.0462)\end{array}$ & $\begin{array}{l}-0.00696 \\
(0.0628)\end{array}$ & $\begin{array}{l}-0.0475 \\
(0.0713)\end{array}$ \\
\hline Unemployed & $\begin{array}{l}-0.0178 \\
(0.0512)\end{array}$ & $\begin{array}{l}-0.00444 \\
(0.0478)\end{array}$ & $\begin{array}{c}0.0317 \\
(0.0445)\end{array}$ & $\begin{array}{c}0.109^{*} \\
(0.0604)\end{array}$ \\
\hline $\begin{array}{l}\text { Observations } \\
\text { Country FE }\end{array}$ & $\begin{array}{c}12,398 \\
\text { Yes }\end{array}$ & $\begin{array}{c}12,398 \\
\text { Yes }\end{array}$ & $\begin{array}{c}12,398 \\
\text { Yes }\end{array}$ & $\begin{array}{c}12,398 \\
\text { Yes }\end{array}$ \\
\hline $\begin{array}{l}\text { Note: Probit } r \\
\text { expectation fo } \\
\text { country-level } \\
{ }^{*} p<0.1\end{array}$ & $\begin{array}{l}\text { sion results from Eq } \\
\text { eernment playing a I } \\
\text { egressions are weigl }\end{array}$ & $\begin{array}{l}\text { on }(1) \text { where the deper } \\
\text { ng role in the specifie } \\
\text { by public weights pro }\end{array}$ & $\begin{array}{l}\text { nt variable is an indic } \\
\text { licy measures. Errors } \\
\text { ed in the survey. }\end{array}$ & $\begin{array}{l}\text { or that equals } 1 \text { for } \\
\text { e clustered at the } \\
.01,{ }^{* \star} p<0.05 \text { and }\end{array}$ \\
\hline
\end{tabular}

Table 24: Assessment of Government Performance - only Advanced Economies

\begin{tabular}{|c|c|c|c|c|c|c|}
\hline & $\begin{array}{c}(1) \\
\text { Overall }\end{array}$ & $\begin{array}{c}(2) \\
\text { Overall }\end{array}$ & $\begin{array}{c}(3) \\
\text { Health }\end{array}$ & $\begin{array}{c}(4) \\
\text { Health }\end{array}$ & $\begin{array}{c}(5) \\
\text { Economic }\end{array}$ & $\begin{array}{c}(6) \\
\text { Economic }\end{array}$ \\
\hline Female & $\begin{array}{l}-0.0285 \\
(0.0189)\end{array}$ & $\begin{array}{l}-0.0389 \\
(0.0218)\end{array}$ & $\begin{array}{c}-0.0574 * * \\
(0.0215)\end{array}$ & $\begin{array}{l}-0.0649 * \\
(0.0297)\end{array}$ & $\begin{array}{c}-0.0622 * * \\
(0.0167)\end{array}$ & $\begin{array}{l}-0.0507^{*} \\
(0.0207)\end{array}$ \\
\hline Young & $\begin{array}{c}0.0235 \\
(0.0258)\end{array}$ & $\begin{array}{c}0.0335 \\
(0.0197)\end{array}$ & $\begin{array}{c}0.0359 \\
(0.0261)\end{array}$ & $\begin{array}{c}0.0563 * * \\
(0.0212)\end{array}$ & $\begin{array}{l}-0.0240 \\
(0.0235)\end{array}$ & $\begin{array}{l}0.00444 \\
(0.0200)\end{array}$ \\
\hline College & $\begin{array}{l}0.00952 \\
(0.0180)\end{array}$ & $\begin{array}{c}-0.000434 \\
(0.0211)\end{array}$ & $\begin{array}{l}-0.00424 \\
(0.0187)\end{array}$ & $\begin{array}{l}-0.0105 \\
(0.0246)\end{array}$ & $\begin{array}{l}0.00680 \\
(0.0191)\end{array}$ & $\begin{array}{c}0.0192 \\
(0.0259)\end{array}$ \\
\hline Urban & $\begin{array}{l}0.00164 \\
(0.0109)\end{array}$ & $\begin{array}{l}0.00247 \\
(0.0228)\end{array}$ & $\begin{array}{l}0.0354 * * \\
(0.0113)\end{array}$ & $\begin{array}{c}0.0389 \\
(0.0204)\end{array}$ & $\begin{array}{l}0.00391 \\
(0.0121)\end{array}$ & $\begin{array}{c}0.000760 \\
(0.0273)\end{array}$ \\
\hline Rich & $\begin{array}{l}0.0344 * * * \\
(0.00614)\end{array}$ & $\begin{array}{c}0.0516 * * * \\
(0.0123)\end{array}$ & $\begin{array}{c}0.0503 * * \\
(0.0194)\end{array}$ & $\begin{array}{l}0.0544 * \\
(0.0250)\end{array}$ & $\begin{array}{l}0.0385^{*} \\
(0.0187)\end{array}$ & $\begin{array}{c}0.0418 \\
(0.0226)\end{array}$ \\
\hline Unemployed & $\begin{array}{l}-0.0376 \\
(0.0321)\end{array}$ & $\begin{array}{l}0.00119 \\
(0.0681)\end{array}$ & $\begin{array}{l}-0.0581^{*} \\
(0.0245)\end{array}$ & $\begin{array}{l}-0.0508 \\
(0.0446)\end{array}$ & $\begin{array}{l}-0.0718^{*} \\
(0.0313)\end{array}$ & $\begin{array}{l}-0.00824 \\
(0.0540)\end{array}$ \\
\hline Small Firm & & $\begin{array}{l}0.00527 \\
(0.0230)\end{array}$ & & $\begin{array}{l}-0.0298 \\
(0.0331)\end{array}$ & & $\begin{array}{c}0.0146 \\
(0.0299)\end{array}$ \\
\hline Tele-workable & & $\begin{array}{c}0.0271 \\
(0.0143)\end{array}$ & & $\begin{array}{l}0.0392^{*} \\
(0.0176)\end{array}$ & & $\begin{array}{c}0.0172 \\
(0.0220)\end{array}$ \\
\hline $\begin{array}{l}\text { Observations } \\
\text { Country FE }\end{array}$ & $\begin{array}{c}6,662 \\
\text { Yes }\end{array}$ & $\begin{array}{c}3,404 \\
\text { Yes }\end{array}$ & $\begin{array}{c}6,662 \\
\text { Yes }\end{array}$ & $\begin{array}{c}3,404 \\
\text { Yes }\end{array}$ & $\begin{array}{c}6,662 \\
\text { Yes }\end{array}$ & $\begin{array}{c}3,404 \\
\text { Yes }\end{array}$ \\
\hline
\end{tabular}

Note: Results from Equation (1) where the dependent variable is an indicator that equals 1 for favorable assessment of the government performance (at least 4 on the scale of 1-5 in the survey). The sample only includes Advanced Economies. Errors are clustered at the country-level and regressions are weighted by public weights provided in the survey. ${ }^{* * *} p<0.01,{ }^{* *} p<0.05$ and ${ }^{*} p<0.1$ 
Table 25: Beliefs about Social and Economic Concerns - Only Advanced Economies

\begin{tabular}{lcccc}
\hline & $\begin{array}{c}(1) \\
\text { Vulnerable more affected }\end{array}$ & $\begin{array}{c}(2) \\
\text { Capitalism is harmful }\end{array}$ & $\begin{array}{c}(3) \\
\text { Prolonged job losses }\end{array}$ & $\begin{array}{c}(4) \\
\text { Threat of automation }\end{array}$ \\
\hline \multirow{2}{*}{ Female } & $0.0264^{*}$ & $0.0326^{*}$ & & 0.00780 \\
Young & $(0.0116)$ & $(0.0148)$ & $(0.0116)$ & 0.000264 \\
& -0.0571 & -0.0266 & $0.0456^{*}$ & $(0.0160)$ \\
College & $(0.0298)$ & $(0.0168)$ & $(0.0216)$ & -0.0124 \\
& 0.00104 & -0.0198 & -0.00743 & $(0.0251)$ \\
Urban & $(0.0108)$ & $(0.0177)$ & $(0.0176)$ & -0.00143 \\
& 0.0514 & 0.0333 & 0.0520 & $(0.0146)$ \\
Rich & $(0.0260)$ & $(0.0313)$ & $(0.0262)$ & $0.0555^{*}$ \\
& -0.0215 & $-0.0588^{* * *}$ & -0.0144 & $(0.0226)$ \\
Unemployed & $(0.0147)$ & $(0.00827)$ & $(0.0113)$ & $-0.0389^{* *}$ \\
& $0.0785^{* *}$ & $0.0763^{* *}$ & $0.0946 * *$ & $(0.0123)$ \\
& $(0.0197)$ & $(0.0199)$ & $(0.0320)$ & 0.00118 \\
Observations & 6,662 & & & $(0.0195)$ \\
Country FE & Yes & 6,662 & 6,662 & 6,662 \\
\hline
\end{tabular}

Note: Results from Equation (1) where the dependent variable is an indicator that equals 1 for favorable assessment of the government performance (at least 4 on the scale of 1-5 in the survey). The sample only includes Advanced Economies. Errors are Note: Results from Equation (1) where the dependent variable is an indicator that equals 1 for strong concerns about social problems (at least 7 on the scale of 1-9 in the survey). The sample only includes Advanced Economies. Errors are clustered at the country -level and regressions are weighted by public weights provided in the survey. ${ }^{* *} p<0.01,{ }^{* *} p<0.05$ and ${ }^{*} p<0.1$ 
Table 26: Policy Preferences in Advanced Economies

\begin{tabular}{lcccc}
\hline & $(1)$ & $(2)$ & $(3)$ & $(4)$ \\
& Give financial relief & Support small business & Manage virus spread & Prep for reopening \\
Female & & & & \\
& -0.00405 & 0.00341 & -0.0161 & -0.00127 \\
Young & $(0.0203)$ & $(0.0245)$ & $(0.0255)$ & $(0.0274)$ \\
& $-0.108^{* * *}$ & $-0.103^{* * *}$ & $-0.0777^{*}$ & $-0.109 * *$ \\
College & $(0.0204)$ & $(0.0177)$ & $(0.0353)$ & $(0.0305)$ \\
& 0.0168 & 0.0275 & 0.0257 & 0.0295 \\
Urban & $(0.0162)$ & $(0.0205)$ & $(0.0169)$ & $(0.0181)$ \\
& $-0.0598^{* *}$ & $-0.0632^{* *}$ & $-0.0482^{*}$ & $-0.0704^{* *}$ \\
Rich & $(0.0199)$ & $(0.0209)$ & $(0.0223)$ & $(0.0180)$ \\
& -0.00979 & -0.00994 & 0.0183 & 0.0175 \\
Unemployed & $(0.0189)$ & $(0.0133)$ & $(0.0223)$ & $(0.0298)$ \\
& -0.00939 & 0.00553 & 0.00874 & $0.0117^{*}$ \\
Observations & $(0.0186)$ & $(0.0122)$ & $(0.0115)$ & $(0.00557)$ \\
Country FE & 6,662 & & & 6,662 \\
\hline
\end{tabular}

Note: Results from Equation (1) where the dependent variable is an indicator that equals 1 for expectation for government playing a leading role in the specified policy measures. The sample only includes Advanced Economies. Errors are clustered at the country-level and regressions are weighted by public weights provided in the survey. ${ }^{* * *} p<0.01,{ }^{* *} p<0.05$ and ${ }^{*} p<0.1$

Table 27: Assessment of Government Performance, Dropping Asian Countries

\begin{tabular}{lcccccc}
\hline & $\begin{array}{c}(1) \\
\text { Overall }\end{array}$ & $\begin{array}{c}(2) \\
\text { Overall }\end{array}$ & $\begin{array}{c}(3) \\
\text { Health }\end{array}$ & $\begin{array}{c}(4) \\
\text { Health }\end{array}$ & $\begin{array}{c}(5) \\
\text { Economic }\end{array}$ & $\begin{array}{c}(6) \\
\text { Economic }\end{array}$ \\
\hline \multirow{3}{*}{ Female } & & & & & & \\
& -0.0270 & $-0.0411^{*}$ & $-0.0506^{*}$ & $-0.0603^{* *}$ & $-0.0604^{* * *}$ & $-0.0552^{* *}$ \\
Young & $(0.0170)$ & $(0.0198)$ & $(0.0209)$ & $(0.0244)$ & $(0.0154)$ & $(0.0169)$ \\
& -0.00178 & 0.0208 & -0.00646 & 0.000969 & -0.0383 & -0.0131 \\
College & $(0.0211)$ & $(0.0136)$ & $(0.0308)$ & $(0.0350)$ & $(0.0199)$ & $(0.0188)$ \\
& 0.0108 & -0.000383 & 0.00478 & 0.00379 & 0.00666 & 0.0251 \\
Urban & $(0.0149)$ & $(0.0166)$ & $(0.0177)$ & $(0.0237)$ & $(0.0156)$ & $(0.0222)$ \\
& -0.00363 & -0.00520 & $0.0404 * *$ & $0.0429 *$ & 0.000125 & -0.00682 \\
Rich & $(0.0129)$ & $(0.0241)$ & $(0.0101)$ & $(0.0204)$ & $(0.0115)$ & $(0.0270)$ \\
& 0.00329 & 0.0210 & 0.0193 & 0.0229 & 0.00969 & 0.0129 \\
Unemployed & $(0.0221)$ & $(0.0184)$ & $(0.0294)$ & $(0.0299)$ & $(0.0235)$ & $(0.0177)$ \\
Small firm & -0.0431 & -0.0164 & $-0.0513^{*}$ & -0.0552 & $-0.0591 *$ & -0.0138 \\
Tele-workable & $(0.0255)$ & $(0.0548)$ & $(0.0228)$ & $(0.0361)$ & $(0.0256)$ & $(0.0427)$ \\
& & 0.0125 & & -0.0376 & & -0.0150 \\
& & $(0.0178)$ & & $(0.0289)$ & & $(0.0328)$ \\
Observations & & $0.0377^{* * *}$ & & 0.0201 & & 0.0143 \\
Country FE & & $(0.00851)$ & & $(0.0194)$ & & $(0.0171)$ \\
& & & & & \\
\end{tabular}

Note: Results from Equation (1) where the dependent variable is an indicator that equals 1 for favorable assessment of the government performance (at least 4 on the scale of 1-5 in the survey). The sample excludes Asian countries. Errors are clustered at the country-level and regressions are weighted by public weights provided in the survey. ${ }^{* * *} \mathrm{p}<0.01,{ }^{* *} \mathrm{p}<0.05$ and ${ }^{*} \mathrm{p}<0.1$ 
Table 28: Beliefs about Social and Economic Concerns, Dropping Asian Countries

\begin{tabular}{lcccc}
\hline & $(1)$ & $(2)$ & $(3)$ & $(4)$ \\
& Vulnerable more affected & Capitalism is harmful & Prolonged job losses & Threat of automation \\
Female & & & & \\
& $0.0536^{*}$ & 0.0200 & 0.0314 & 0.0191 \\
Young & $(0.0227)$ & $(0.0115)$ & $(0.0204)$ & $(0.0211)$ \\
& $-0.0652^{* *}$ & $-0.0296^{*}$ & 0.0108 & -0.0319 \\
College & $(0.0209)$ & $(0.0126)$ & $(0.0240)$ & $(0.0246)$ \\
& 0.0157 & -0.00918 & 0.0112 & 0.00939 \\
Urban & $(0.0139)$ & $(0.0204)$ & $(0.0143)$ & $(0.0121)$ \\
& $0.0537^{*}$ & 0.0262 & 0.0460 & 0.0483 \\
Rich & $(0.0272)$ & $(0.0339)$ & $(0.0291)$ & $(0.0252)$ \\
& -0.00723 & $-0.0512^{* * *}$ & -0.000354 & -0.0232 \\
Unemployed & $(0.0138)$ & $(0.0120)$ & $(0.0105)$ & $(0.0197)$ \\
& $0.0631^{* *}$ & $0.0778^{* * *}$ & $0.0968^{* *}$ & -0.0195 \\
& $(0.0250)$ & $(0.0160)$ & $(0.0281)$ & $(0.0236)$ \\
Observations & 7,856 & 7,856 & & 7,856 \\
Country FE & Yes & Yes & 7,856 & Yes \\
\hline
\end{tabular}

Note: Results from Equation (1) where the dependent variable is an indicator that equals 1 for strong concerns about socio-economic problems (at least 7 on the scale of 1-9 in the survey). The sample excludes Asian countries. Errors are clustered at the country-level and regressions are weighted by public weights provided in the survey. ${ }^{* \star *} \mathrm{p}<0.01$, ${ }^{* *} p<0.05$ and ${ }^{*} p<0.1$

\begin{tabular}{lcccc}
\hline \multicolumn{5}{c}{ Table 29: Policy Preferences, Dropping Asian Countries } \\
\hline & $(1)$ & $(2)$ & $(3)$ & $(4)$ \\
& Give financial relief & Support small business & Manage virus spread & Prep for reopening \\
\hline \multirow{2}{*}{ Female } & & & & \\
& 0.000289 & -0.00130 & -0.0233 & 0.00271 \\
Young & $(0.0162)$ & $(0.0224)$ & $(0.0251)$ & $(0.0221)$ \\
& $-0.0859^{* *}$ & $-0.0828^{* *}$ & $-0.0603^{*}$ & $-0.0871^{* *}$ \\
College & $(0.0282)$ & $(0.0294)$ & $(0.0291)$ & $(0.0302)$ \\
& 0.0162 & 0.0228 & 0.0256 & 0.0250 \\
Urban & $(0.0137)$ & $(0.0182)$ & $(0.0149)$ & $(0.0168)$ \\
& $-0.0674^{* *}$ & $-0.0605^{* *}$ & $-0.0506^{*}$ & $-0.0726^{* * *}$ \\
Rich & $(0.0188)$ & $(0.0232)$ & $(0.0248)$ & $(0.0184)$ \\
& -0.0141 & -0.0140 & 0.00791 & -0.00309 \\
Unemployed & $(0.0210)$ & $(0.0142)$ & $(0.0306)$ & $(0.0321)$ \\
& -0.000969 & 0.00399 & 0.0119 & 0.0260 \\
Observations & $(0.0191)$ & $(0.0177)$ & $(0.0107)$ & $(0.0194)$ \\
Country FE & 7,856 & & & 7,856 \\
\hline
\end{tabular}

Note: Results from Equation (1) where the dependent variable is an indicator that equals 1 for expectation for government playing a leading role in the specified policy measures. The regressions exclude Asian countries. Errors are clustered at the country-level and regressions are weighted by public weights provided in the survey. ${ }^{* * *} p<0.01$, ${ }^{* *} p<0.05$ and ${ }^{*} p<0.1$ 